\title{
c-Myc is essential for vasculogenesis and angiogenesis during development and tumor progression
}

\author{
Troy A. Baudino, ${ }^{1}$ Catriona McKay, ${ }^{1}$ Helene Pendeville-Samain, ${ }^{1}$ Jonas A. Nilsson, ${ }^{1}$ \\ Kirsteen H. Maclean, ${ }^{1}$ Elsie L. White, ${ }^{1}$ Ann C. Davis, ${ }^{3}$ James N. Ihle, ${ }^{1,2,4}$ and John L. Cleveland ${ }^{1,4,5}$ \\ ${ }^{1}$ Department of Biochemistry and ${ }^{2}$ Howard Hughes Medical Institute, St. Jude Children's Research Hospital, Memphis, \\ Tennessee 38105, USA; ${ }^{3}$ Pharmaceutical Division, Bayer Corporation, West Haven, Connecticut 06516, USA; ${ }^{4}$ Department \\ of Molecular Sciences, University of Tennessee, Memphis, Tennessee 38163, USA
}

c-Myc promotes cell growth and transformation by ill-defined mechanisms. c-myc ${ }^{-/-}$mice die by embryonic day 10.5 (E10.5) with defects in growth and in cardiac and neural development. Here we report that the lethality of c-myc $\mathrm{c}^{-/-}$embryos is also associated with profound defects in vasculogenesis and primitive erythropoiesis. Furthermore, c-myc $\mathrm{c}^{-/-}$embryonic stem (ES) and yolk sac cells are compromised in their differentiative and growth potential. These defects are intrinsic to c-Myc, and are in part associated with a requirement for $\mathrm{c}-$ Myc for the expression of vascular endothelial growth factor (VEGF), as VEGF can partially rescue these defects. However, $\mathrm{c}-\mathrm{Myc}$ is also required for the proper expression of other angiogenic factors in ES and yolk sac cells, including angiopoietin-2, and the angiogenic inhibitors thrombospondin-1 and angiopoietin-1. Finally, c-myc ${ }^{-/-}$ES cells are dramatically impaired in their ability to form tumors in immune-compromised mice, and the small tumors that sometimes develop are poorly vascularized. Therefore, c-Myc function is also necessary for the angiogenic switch that is indispensable for the progression and metastasis of tumors. These findings support the model wherein c-Myc promotes cell growth and transformation, as well as vascular and hematopoietic development, by functioning as a master regulator of angiogenic factors.

[Keywords: c-Myc; VEGF; vasculogenesis; angiogenesis; tumorigenesis]

Received July 18, 2002; revised version accepted August 6, 2002.

c-Myc functions are necessary and sufficient for the entry of most cells into the DNA synthetic $(\mathrm{S})$ phase of the cell cycle (Eilers et al. 1989; de Alboran et al. 2001; Trumpp et al. 2001), and MYC family genes are commonly activated in cancer. However, the precise mechanisms by which c-Myc promotes cell growth and transformation have not been resolved. Under physiological conditions c-myc expression is dependent on mitogens. This control is lost in cancer cells, resulting in elevated levels of c-Myc oncoprotein. In normal cells c-Myc activation triggers the apoptotic program (Askew et al. 1991; Evan et al. 1992), and thus c-Myc-induced transformation generally does not occur until there is a loss of function of apoptotic regulators. In particular, c-Myc triggers the ARF-Mdm2-p53 tumor suppressor pathway, and this prevents c-Myc-induced lymphomagenesis (Zindy et al. 1998; Eischen et al. 1999). However, c-Myc is also continuously required to maintain the trans-

\footnotetext{
${ }^{5}$ Corresponding author.

E-MAIL john.cleveland@stjude.org; FAX (901) 525-8025.

Article and publication are at http://www.genesdev.org/cgi/doi/10.1101/ gad.1024602.
}

formed state (Felsher and Bishop 1999; Jain et al. 2002; Pelengaris et al. 2002), and disabling apoptosis alone is generally considered insufficient to promote tumorigenesis. Thus, Myc oncoproteins must provide other functions that initiate and/or sustain malignancy.

Tumor progression and maintenance requires the development of an ample blood supply, which ensures the delivery of oxygen, nutrients, and growth factors. This requires the development of both immature and mature blood vessels. First, vasculogenesis, which is regulated by vascular endothelial growth factor (VEGF) and its receptors Flk-1 and Flt-1, establishes a primitive vascular network from newly differentiated endothelial cells that assemble into vascular tubes. Second, angiogenesis promotes the sprouting and remodeling of capillaries from these preexisting vessels (Risau 1997). This process requires the dissociation of pericytes from endothelial cells, and is regulated by interplay between angiopoietin-1 (ANG-1) and angiopoietin-2 (ANG-2) and signaling through their receptor Tie2 (Hanahan 1997). In the adult, angiogenesis is a tightly controlled process that regulates neovascularization during ovulation, placental development, and wound healing. 
Uncontrolled angiogenesis plays an important role during tumor growth (Hanahan and Folkman 1996), and the sprouting of new blood vessels into tumors suggests that angiogenesis is necessary for a successful malignancy. Angiogenesis is provoked early during tumor progression and occurs in part in response to environmental cues, in particular hypoxia, which regulates the expression of angiogenic factors critical for vasculogenesis and angiogenesis in tumors and during embryogenesis (Carmeliet et al. 1998; Iyer et al. 1998; Ryan et al. 1998). However, genetic changes in cancer may also flip the angiogenic switch. For example, in cell lines loss of p53 elevates VEGF levels (Volpert et al. 1997), whereas the oncogenes $\mathrm{v}$-src, c-jun, and c-myc suppress the expression of the anti-angiogenic factor thrombospondin-1 (TSP-1; Mettouchi et al. 1994; Slack and Bornstein 1994; Tikhonenko et al. 1996). Furthermore, transgenic studies have shown that transformation induced by several oncoproteins, including $\mathrm{c}-\mathrm{Myc}$, is sufficient to induce an angiogenic response and the expression of VEGF (Kerbel et al. 1998; Pelengaris et al. 1999). However cause-effect relationships are difficult to establish, given that hypoxia accompanies tumor expansion in vivo.

VEGF is a critical regulator of both vasculogenesis and angiogenesis (Hanahan 1997; Carmeliet and Collen 1999|. Gene targeting in mice has shown that VEGF, Flk-1, and Flt-1 all have essential roles in early development, with lethality occurring between embryonic days 8.5 and 10.5 (E8.5 and E10.5; Fong et al. 1995; Shalaby et al. 1995; Carmeliet et al. 1996; Ferrara et al. 1996). Mouse embryos deficient in c-myc also die in utero at E10.5, and their lethality has been attributed to a delay in growth and cardiac and neural defects (Davis et al. 1993).

Here we report that c-Myc deficiency results in profound defects in vasculogenesis, angiogenesis, and primitive erythropoiesis, and that these defects are associated with a failure in VEGF expression, and with improper expression of TSP-1, ANG-1, and ANG-2. The data support the model whereby c-Myc promotes tumorigenesis by functioning as a master regulator of cytokines necessary for growth, vasculogenesis, and angiogenesis.

\section{Results}

\section{c-Myc loss impairs vasculogenesis and angiogenesis}

The lethality of several mouse knockouts at E8.5-E10.5, including the hypoxia regulators HIF-1 $\alpha$ and ARNT (Kozak et al. 1997; Maltepe et al. 1997; Iyer et al. 1998; Ryan et al. 1998; Adelman et al. 1999), and VEGF (Carmeliet et al. 1996; Ferrara et al. 1996), and its receptors Flk-1 (Shalaby et al. 1995) and Flt-1 (Fong et al. 1995), is associated with a failure in primitive erythropoiesis and/ or vasculogenesis. In situ hybridization studies have established that c-myc is widely expressed at this stage of development (Downs et al. 1989). To assess whether cMyc protein was expressed in the primitive hematopoietic cells of the blood islands, and/or in the mesodermal layer of the yolk sac membrane that gives rise to the vasculature (Wagner 1980), immunofluorescence analyses of E9.5 yolk sacs were performed with a c-Myc-specific antiserum. Primitive erythrocytes were identified by staining with an antibody for Ter119, an antigen expressed on erythroid cells (Ilkuta et al. 1990). Most of the cells within the blood islands were erythroid, yet they did not express c-Myc, and c-Myc was also not expressed in definitive erythrocytes that arise at later stages of development (E11.5 and beyond; data not shown). Rather, c-Myc expression was confined to the nuclei of endothelial-like cells in the yolk sac mesoderm (Fig. 1). The endothelial nature of these c-Myc-expressing cells was confirmed by costaining with antibody for the endothelial cell surface marker PECAM-1, which showed a nearly complete overlap in c-Myc and PECAM-1 expression (Fig. 1).

The expansion of endothelial cells that form the vasculature is severely compromised in VEGF-deficient, Flk-1-deficient, and Flt-1-deficient embryos. The selective expression of c-Myc in endothelial cells of the yolk sac suggested that the lethality of $\mathrm{c}-\mathrm{myc}^{-/-}$embryos could reflect similar defects in vasculogenesis. To address this issue we rederived $\mathrm{c}-\mathrm{myc}^{+/-}$mice using AB2.1 embryonic stem (ES) cells heterozygous for a disrupted c-myc allele (Davis et al. 1993). Timed matings were then performed with $\mathrm{c}-\mathrm{myc}^{+/-}$intercrosses. Histological examination of transverse sections of c- $\mathrm{myc}^{-/-}$E9.5 embryos revealed that the yolk sac of c- $\mathrm{myc}^{-/-}$embryos was abnormal, with only a 1-2-cell layer sac compared with a 3-5-cell layer yolk sac in wild-type embryos (Fig. 2A).
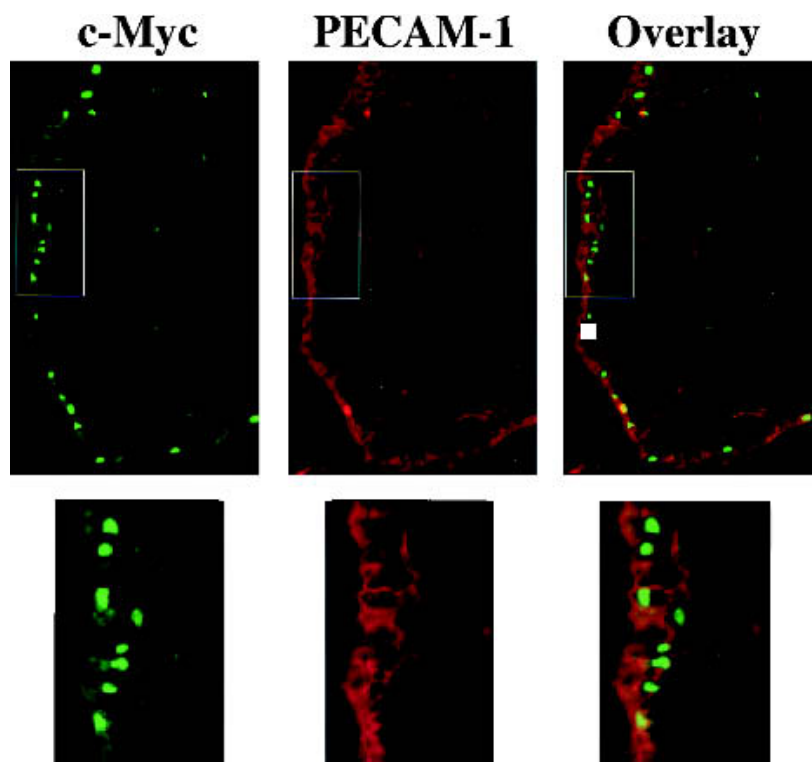

Figure 1. c-Myc is expressed in endothelial cells of the embryonic E8.5 yolk sac membrane. Endothelial cells were detected by immunofluorescence analyses with an antibody specific for PECAM-1 (red stain), which is expressed on the cell surface of endothelial cells. c-Myc expression was detected with a mousespecific c-Myc antibody (green stain) and was largely confined to nuclei. Overlay shows that c-Myc-expressing cells (with green nuclei) also expressed PECAM-1. For clarity, the boxed areas in the top panels were magnified and are shown below. 
A

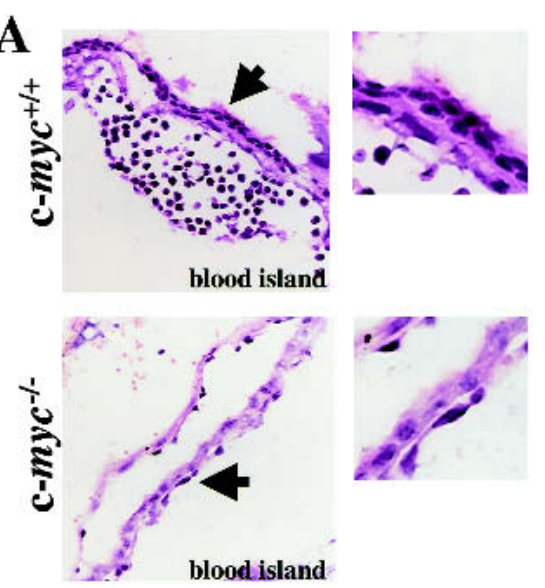

D

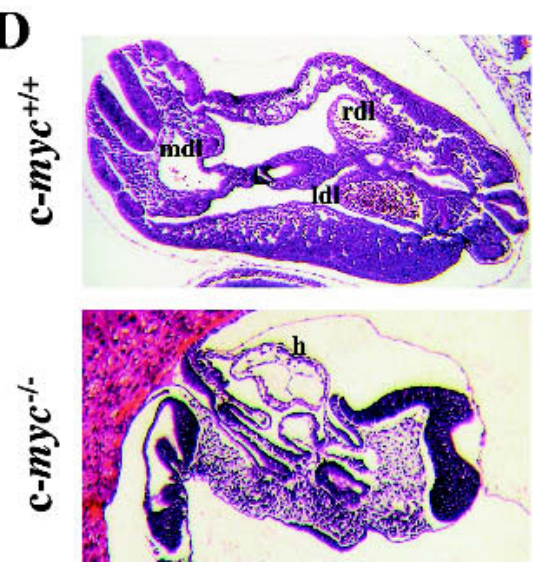

B

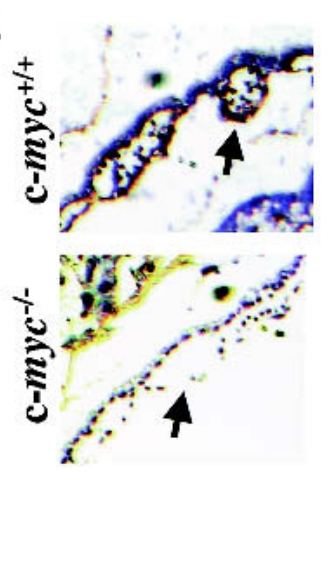

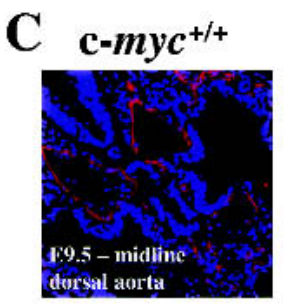

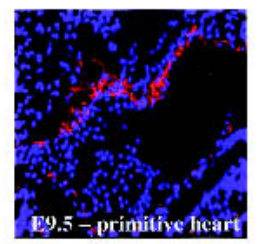

$\mathbf{c}-m y c^{-/-}$
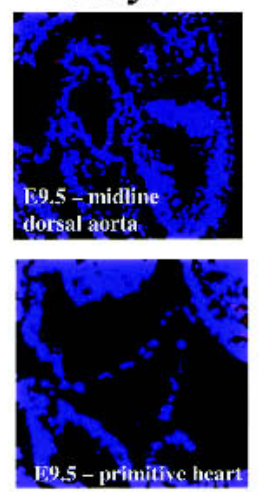

$\mathbf{E}$

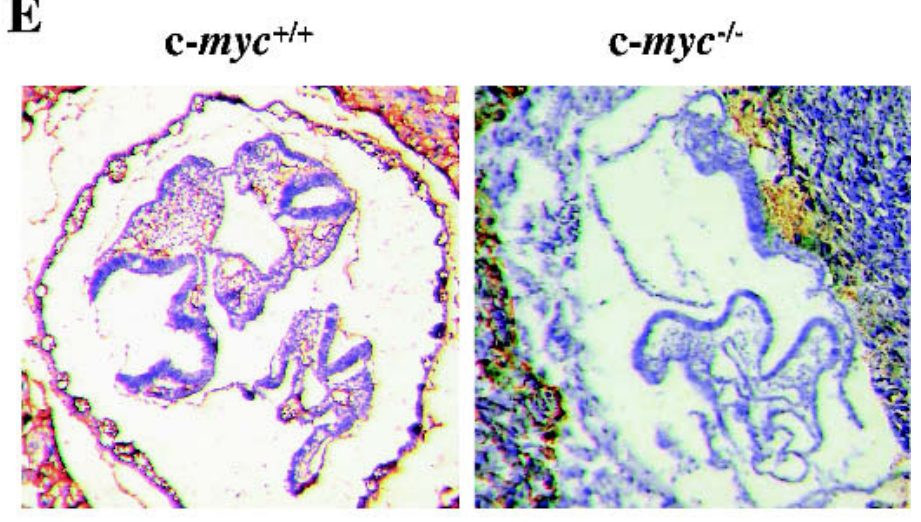

Figure 2. c- $m y c^{-/-}$embryos have marked defects in vasculogenesis and angiogenesis. (A) Histological examination of H\&E-stained yolk sacs of E8.5 wild-type versus c- $\mathrm{myc}^{-/-}$embryos. Arrows indicate area magnified to determine detailed morphology of cells lining the blood island (right panels). (B) IHC analyses of E9.5 yolk sacs from wild-type and c-myc ${ }^{-/-}$embryos with PECAM-1 antibody (brown stain). Arrows indicate blood islands. $(C)$ Histological analyses of transverse sections of wild-type and c-myc ${ }^{-/-}$E9.5 embryos (top panels) and primitive hearts (bottom panels) with PECAM-1 antibody (red), counterstained with DAPI (blue). (D) H\&E staining of wild-type and c- $\mathrm{myc}^{-/-}$embryos. (E) IHC analyses of E9.5 wild-type and c-myc ${ }^{-/-}$embryos with PECAM-1 antibody (brown stain).

Furthermore, immunohistochemical (IHC) analyses with PECAM-1 antibody showed that PECAM-1 ${ }^{+}$cells were virtually absent in the yolk sacs of E9.5 c- $\mathrm{myc}^{-/-}$ embryos (Fig. 2B). Staining with H\&E (Fig. 2D) and immunofluorescence (Fig. 2C) and IHC (Fig. 2E) analyses with PECAM-1 antibody revealed that vascular defects extended to the embryo proper. As expected (Davis et al. 1993), H\&E staining confirmed that c-myc ${ }^{-/-}$embryos are smaller than their wild-type littermates, and showed that they lack clearly defined vasculature structures, including the dorsal aorta (Fig. 2D). In wild-type embryos, PECAM $-1^{+}$cells were abundant throughout the embryo, and were also detected in small vessels sprouting in the periphery (Fig. 2C,E), a site of active angiogenesis. Although PECAM- $1^{+}$cells were abundant in the placenta surrounding c- $\mathrm{myc}^{-/-}$embryos (Fig. 2E), they were totally absent in c-myc ${ }^{-/-}$embryos (Fig. 2C-E). TUNEL analyses showed that wild-type and c-myc $\mathrm{c}^{-/}$embryos are equivalent in the low levels of apoptosis that can be detected. However, staining with an antibody specific to phosphorylated histone $\mathrm{H} 3$ (which detects cells in mitosis) showed reduced proliferation in c-myc ${ }^{-/-}$embryos and yolk sacs versus wild-type embryos (Supplementary Fig. 1; see Supplementary Material at http://www.genesdev. org). Thus, c-Myc is required for proper vasculogenesis and angiogenesis during embryonic development, and cMyc loss drastically compromises the growth and expansion of PECAM-1 ${ }^{+}$endothelial cells.

\section{$c-M y c$ is required for primitive erythropoiesis}

Embryonic vascular development initiates from the hemangioblast, a progenitor cell that also gives rise to primitive hematopoietic cells (Choi et al. 1998). We therefore assessed whether c-Myc loss was also associated with defects in primitive erythropoiesis. Indeed, analyses of c- $\mathrm{myc}^{-/-}$E8.5 and E9.5 yolk sacs revealed profound defects in numbers of primitive erythroid $\left(\right.$ Ter1 $\left.19^{+}\right)$cells in the blood islands (Figs. 2A, 3A). Furthermore, there were severe reductions in the numbers of erythroid cells in the primitive heart of c- $\mathrm{yc}^{-/-} \mathrm{em}$ bryos (Fig. 3B). Thus, loss of c-Myc also compromises primitive erythropoiesis. 
A

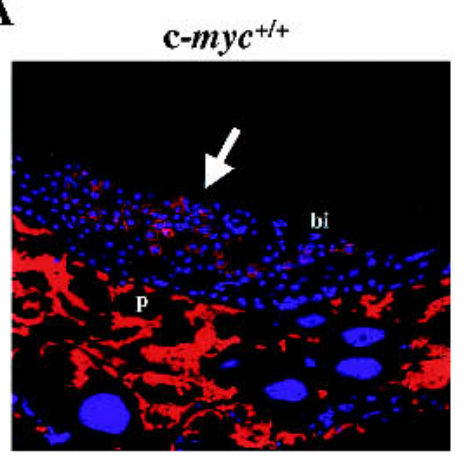

B

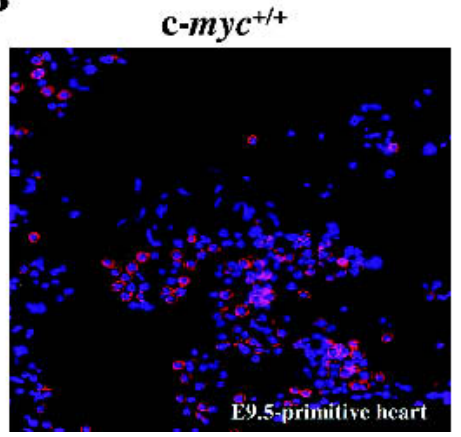

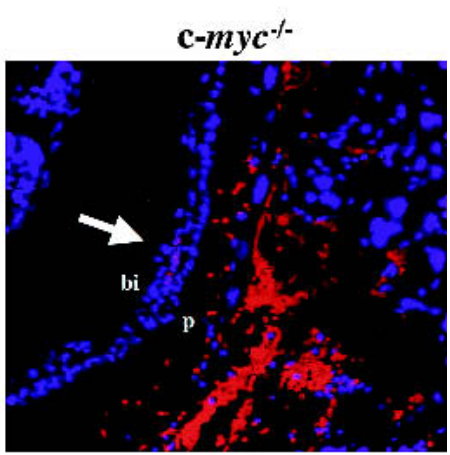

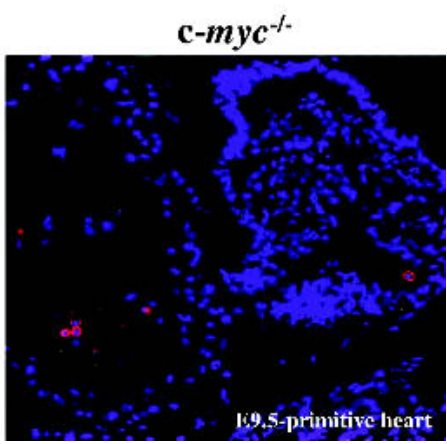

Figure 3. c- $m y c^{-/-}$embryos have marked defects in primitive erythropoiesis. (A) Immunofluorescence analyses of transverse sections of E9.5 embryos using the erythroid-specific antibody Ter119 (red), counterstained with DAPI (blue). White arrows indicate blood islands. Bright red nonnucleated cells are maternal blood cells present in the placenta. $(B)$ Immunofluorescence analyses of the cardiac region of E9.5 $\mathrm{c}-\mathrm{myc}^{-/-}$and wild-type embryos using Ter119 antibody and DAPI.
$c-M y c$ is required for proper differentiation of embryonic stem cells

ES cells form primitive embryoid bodies (EBs) when deprived of leukemia inhibitory factor (LIF) and plated in methylcellulose containing stem cell factor. To address whether c-Myc loss had effects on EB formation, we used isogenic wild-type, c- $m y c^{+/-}$, and c- $m y c^{-/-}$ ES cells (Davis et al. 1993). When maintained in LIF medium, c- $\mathrm{myc}^{+/-}$ES cells proliferated at a rate similar to that of wild-type cells, whereas $\mathrm{c}-\mathrm{myc}^{-/-} \mathrm{ES}$ cells grew at slightly decreased rates (Fig. 4A). However, the numbers of EBs derived from c-myc ${ }^{-/}$ES cells were markedly reduced compared with those formed by wild-type ES cells (Fig. 4B). Haploinsufficiency effects of c-Myc loss were also evident as c- $\mathrm{myc}^{+/-}$ES cells generated intermediate numbers of EBs (Fig. 4B). Therefore, c-Myc loss impairs the primary differentiation of ES cells.

The marked deficits in numbers of primitive erythrocytes in c- $\mathrm{myc}^{-/-}$embryos could be caused by defects in an early hematopoietic stem cell, and/or be a secondary consequence of defects in the vasculature. Differentiating cells within EBs form secondary hematopoietic colonies when replated in methylcellulose containing specific cytokines (Kennedy et al. 1997). We therefore assessed whether EBs derived from c-myc $\mathrm{c}^{-/-}$ES cells could form secondary hematopoietic colonies. c-myc $c^{-/-}$. derived EBs were only modestly reduced in their ability to form BFU-E and various myeloid (SCF, IL-3, and GM-CSF) cell colonies (Supplementary Fig. 2; see Supplementary Material at http://www.genesdev.org); thus, c-myc $\mathrm{c}^{-/-}$-derived EBs can differentiate into hema- topoietic lineage cells. However, there were significant reductions in the numbers of CFU-E colonies generated by c- $\mathrm{yyc}^{-/-}$-derived EBs (Fig. 4C). To address whether this defect was also manifest in vivo, we performed colony assays on E9.5 yolk sacs isolated from wild-type, $\mathrm{c}-\mathrm{myc}^{+/-}$, and c-myc $\mathrm{c}^{-/-}$embryos. Yolk sac cells from wild-type embryos generated erythroid-like and myeloid-like colonies when plated without cytokines, but c- $\mathrm{myc}^{-/-}$yolk sac cells did not (Fig. 4D). Furthermore, E9.5 c- $\mathrm{myc}^{-/-}$yolk sac cells generated significantly reduced numbers of CFU-E colonies versus those generated by wild-type yolk sac cells (Fig. 4D). Therefore, the reduction in primitive erythrocytes in c-myc $c^{-/}$embryos may reflect the combined effects of a lack of a proper supporting vasculature and defects in a primitive hematopoietic stem cell.

\section{c-Myc loss impairs the tumorigenicity of ES cells}

ES cells are tumorigenic when injected into immunecompromised mice and give rise to large teratomas. ES cells lacking VEGF are severely compromised in their tumor formation (Ferrara et al. 1996). Because c-myc ${ }^{-/-}$ embryos were defective in vasculogenesis, we injected wild-type, c- $\mathrm{myc}^{+/-}$, and $\mathrm{c}-\mathrm{myc}^{-/-}$ES cells subcutaneously into the flanks of Scid mice and evaluated their tumorigenic potential. By 3-5 wk, wild-type ES cells generated large local teratomas in $100 \%$ of injected mice. Tumor size was reduced by half in Scid mice injected with $\mathrm{c}-\mathrm{myc}^{+/-} \mathrm{ES}$ cells, and was further reduced in mice injected with c-myc $\mathrm{c}^{-/}$ES cells (Fig. 5A). Furthermore, when followed with time the rate of tumor growth was 

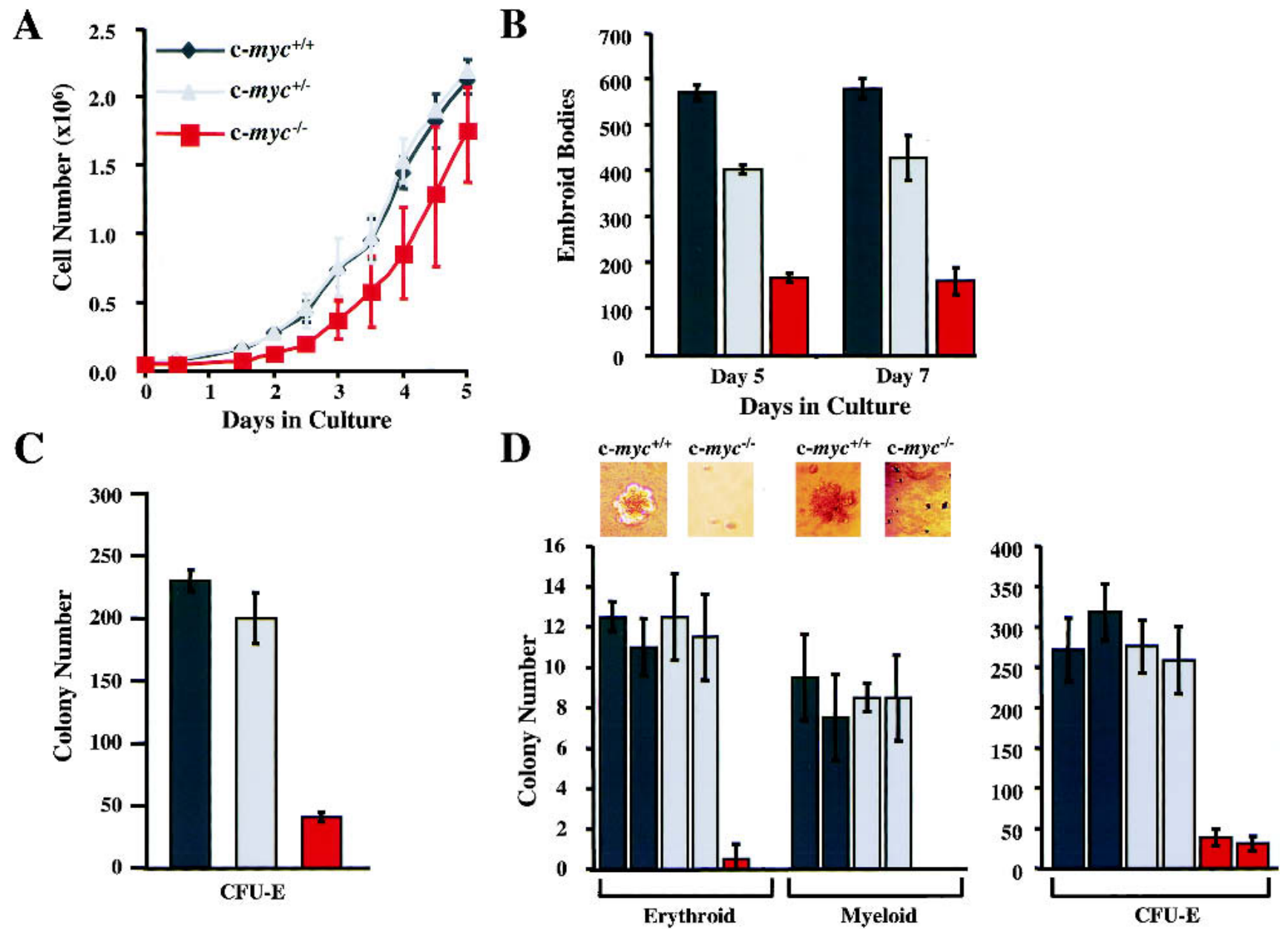

Figure 4. $\quad \mathrm{c}-\mathrm{myc}^{-/-}$ES cells are impaired in their in vitro differentiation. (A) Growth rates of wild-type (dark gray), c-myc $c^{+/-}$(light gray), and c- $\mathrm{myc}^{-1-}$ (red) ES cells are shown in triplicate. (B) c-Myc deficiency impairs the primary differentiation of ES cells. The indicated ES cells were induced to undergo primary differentiation and after 5 or $7 \mathrm{~d}$ in culture, the numbers of EBs were determined. The results shown are the mean of three experiments performed in duplicate. $(C) \mathrm{c}-\mathrm{myc}^{-/-}$ES cells are selectively impaired in secondary CFU-E colony formation. The indicated cells, wild-type (dark gray), c-myc $c^{+-}$(light gray), and c-myc $c^{-/-}$(red), were plated in methylcellulose for $7 \mathrm{~d}$. Then the EBs were dispersed and plated in methylcellulose containing Epo (CFU-E). Colony numbers were determined after $4 \mathrm{~d}$. The data shown are representative of three experiments performed in duplicate. The mean number of colonies $+/-$ the standard deviation is shown. $(D)$ Hematopoietic progenitor colony assays were performed on E9.5 wild-type and c-myc $c^{-/-}$yolk sacs cultured in methylcellulose. Examples of erythroid-like and myeloid-like colonies formed by wild-type and c-myc ${ }^{-/-}$yolk sac cells in the absence of cytokines are shown above the left panel. In the right panel is shown CFU-E colony assays performed on individual E9.5 yolk sacs isolated from wild-type, c- $m y c^{+/-}$, and c- $m y c^{-/-}$yolk sacs, performed in duplicate.

impaired in mice injected with $\mathrm{c}-m y c^{-/-}$ES cells, and these tumors failed to grow beyond $0.75 \mathrm{~g}$ in size. Finally, only a fraction of mice $(60 \%)$ injected with c-myc ${ }^{-/-}$ES cells developed tumors (Fig. 5A).

Vascularization of tumors is required when their size exceeds the capacity to obtain oxygen and nutrients by passive diffusion. Tumors bypass this hurdle by secreting angiogenic factors that promote vessel growth into the tumor. The small size of tumors derived from c-myc $c^{-/-}$ES cells could reflect defects in either growth and/or vascularization. These tumors did grow at a reduced rate (Fig. 5A), yet visual inspection revealed that those arising from c- $\mathrm{myc}^{-/-}$ES cells were pale. To directly assess tumor vascularization, they were evalu- ated histologically (Fig. 5B) or moribund animals were perfused with latex (Fig. 5C). The large tumors arising from wild-type ES cells were highly vascularized, with large vessels and obvious capillary beds (Fig. 5B,C). In contrast, very few vessels were observed in the small tumors that arose from c-myc $c^{-1-}$ ES cells (Fig. 5B,C). In addition, IHC of wild-type ES cell-derived tumors with antibody specific to $\alpha$-smooth muscle actin $(\alpha-\mathrm{SMA})$ revealed large numbers of $\alpha-\mathrm{SMA}^{+}$mature vessels, whereas tumors derived from c-myc ${ }^{-/-}$ES cells had marked decreases in $\alpha-\mathrm{SMA}^{+}$cells and smaller vessels (Supplementary Fig. 3; see Supplementary Material at http://www.genesdev.org). Therefore, c-Myc loss impairs the tumorigenic potential of ES cells, and this is 
$\mathbf{A}$

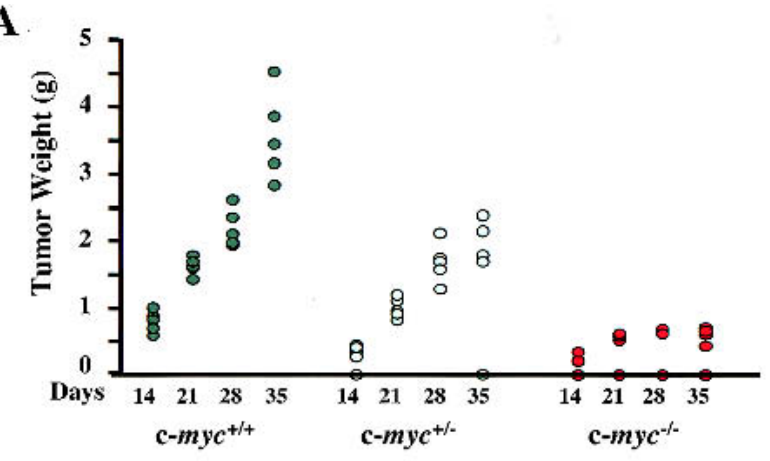

B

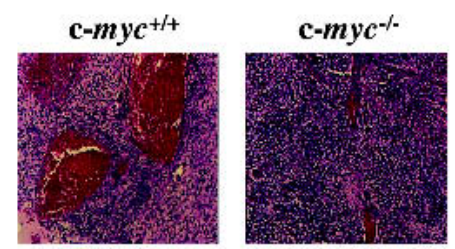

C
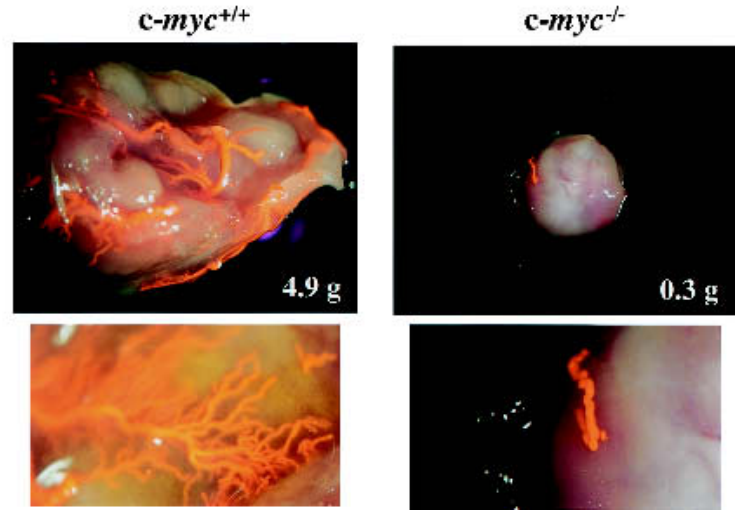

Figure 5. c-myc $c^{-/-}$ES cells are impaired in tumorigenic and vasculogenic potential. $(A)$ The weight of tumors arising in Scid mice following injection of wild-type (dark gray circles), $\mathrm{c}-\mathrm{myc}^{+/-}$(light gray circles), or c- $\mathrm{yyc}^{-/-}$(red circles) ES cells is shown. Tumors were harvested at the indicated intervals. $(B)$ $H \& E$ staining of paraffin sections of tumors arising from c- $m y c^{-/-}$ES cells, compared with wild-type ES-cell-derived teratomas. $(C)$ Dying Scid mice injected with wild-type or c-myc $c^{-/-}$ ES cells were anesthetized and perfused with latex. The tumors were then resected and processed as described in Materials and Methods. Representative tumors are shown. The lower panels are magnified views showing capillary beds of the respective tumors.

associated with marked defects in vascularization and angiogenesis.

\section{c-Myc loss impairs VEGF expression}

The combined deficits of $\mathrm{c}-\mathrm{myc}^{-/-}$progenitors were reminiscent of the phenotypes of mice lacking VEGF, Flt-1, or Flk-1. We therefore examined possible links between c-Myc and these regulators of vasculogenesis. ES cells produce and secrete VEGF (Carmeliet et al. 1996). We therefore determined the levels of VEGF secreted by wild-type, c- $\mathrm{yyc}^{+/-}$, and c- $\mathrm{myc}^{-/-}$cells by ELISA. Loss of one c-myc allele resulted in a modest reduction in VEGF, and VEGF production was further reduced in c- $m y c^{-/-}$ES cells (Fig. 6A). Northern blot and RT-PCR analyses established that the lower VEGF levels produced by $\mathrm{c}-\mathrm{myc}^{-1-}$ ES cells were caused by severe reductions in $V E G F$ RNA (Fig. 6B). Therefore c-Myc loss selectively compromises VEGF expression in ES cells.

To address whether defects in VEGF expression were also manifest in c- $m y \mathrm{c}^{-/-}$embryos, we performed in situ hybridization. VEGF was highly expressed in cells lining the wild-type E8.5 yolk sac (Fig. 6C), which also express c-Myc (Fig. 1). In contrast, VEGF expression was markedly reduced in the yolk sac of c-myc $c^{-/}$embryos (Fig. $6 C)$. Therefore, c-Myc is required for proper VEGF expression during development.

The reduction in VEGF expression in c-myc ${ }^{-/-}$yolk sac endothelial cells and ES cells suggested that VEGF might be a transcriptional target of c-Myc. Indeed, restoration of c-Myc expression by transfecting c-myc $\mathrm{c}^{-/}$ cells with a phosphoglycerate kinase (PGK) promoterdriven c-Myc expression plasmid (to levels of c-Myc protein present in wild-type ES cells; data not shown), restored VEGF RNA levels to those found in wild-type ES cells (Fig. 6B). Unfortunately, attempts to overexpress Myc-ER ${ }^{\mathrm{TM}}$, a chimeric form of c-Myc that can be conditionally activated by the addition of the estrogen receptor (ER) agonist tamoxifen (TM), were toxic to ES cells. Nonetheless, the failure of $\mathrm{c}-\mathrm{myc}^{-/-}$ES cells to express VEGF is intrinsic, as restoration of c-Myc levels reestablished VEGF expression (Fig. 6B).

To address whether VEGF expression could be induced by Myc, we infected wild-type mouse embryonic fibroblasts (MEFs) with the MSCV-Myc-ER ${ }^{\text {TM}}$-IRES-GFP retrovirus, which expresses green fluorescence protein (GFP) in cis from an internal ribosome entry site (IRES; Eischen et al. 1999). In addition, this virus was used to infect immortal c-myc ${ }^{-/-}$Ratla fibroblasts in which both alleles of c-myc have been inactivated by homologous recombination (Mateyak et al. 1997). Infected cells were selected by FACS for GFP expression and expanded in culture; infected cells expressed high levels of the Myc-ER ${ }^{\mathrm{TM}}$ protein by immunoblot (data not shown). Serum-starved cells were then treated with of 4-hydroxytamoxifen (4-HT) to activate Myc-ER ${ }^{\mathrm{TM}}$, and RTPCR was performed for VEGF, for ornithine decarboxylase $(O D C)$, a direct transcription target induced by cMyc (Bello-Fernandez et al. 1993), and for GAPDH (Fig. 6D). Like $O D C, V E G F$ expression was induced in both Myc-ER ${ }^{\mathrm{TM}}$-expressing cells following the addition of 4-HT (Fig. 6D), and this induction was also obvious at the level of VEGF protein in Myc-ER ${ }^{\mathrm{TM}}$-expressing MEFs treated with 4-HT, and in Myc-expressing Ratla cells (Fig. 6E). Therefore, Myc can conditionally activate $V E G F$ expression in primary and immortal fibroblasts, and overexpression of Myc also augments VEGF expression.

To address whether VEGF expression could be directly activated by $M y c-E R^{\mathrm{TM}}$, we also pretreated Myc-ER ${ }^{\mathrm{TM}}$ expressing MEFs with cycloheximide (Chx) for $30 \mathrm{~min}$ (which blocked de novo protein synthesis by $>95 \%$ ) prior 
Baudino et al.

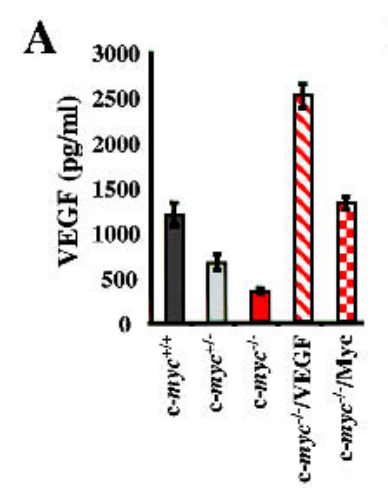

B

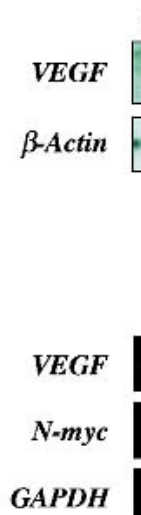

D

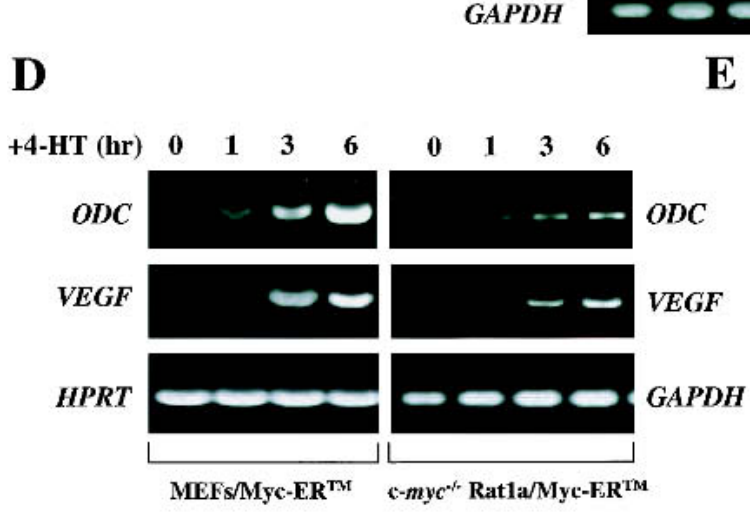

$\mathbf{E}$

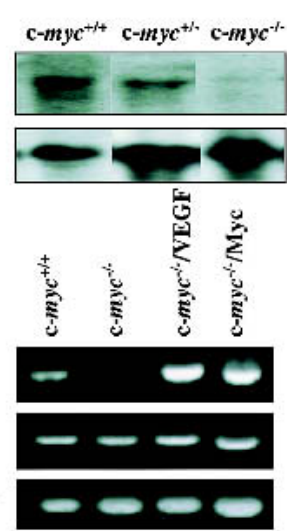

C
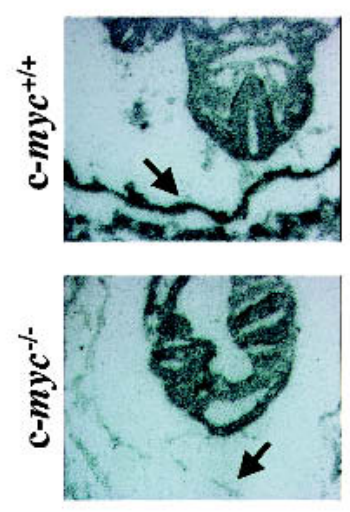

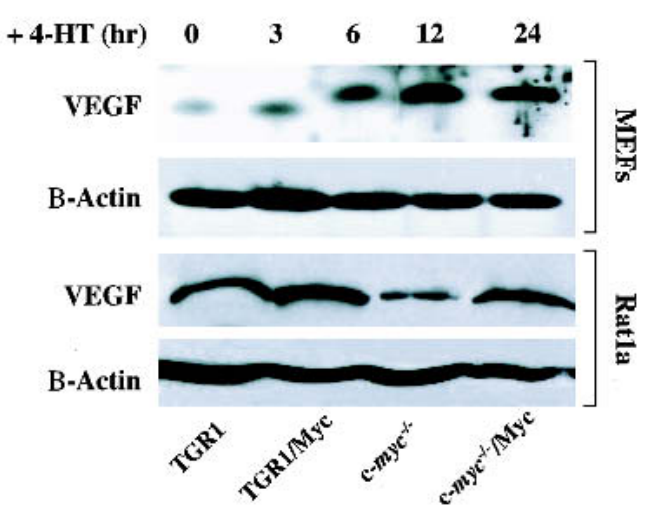

Figure 6. c-Myc loss impairs VEGF expression. (A) VEGF production by wild-type (dark gray), c-myc $c^{+/-}\left(\right.$light gray), and c-myc $c^{-/-}\left(\mathrm{red}^{-}\right)$ ES cells. The indicated cells were plated as described in Materials and Methods, and VEGF levels were determined by ELISA. c-myc ${ }^{-/-}$ ES cells transduced with PGK-Myc (red checkerboard) or PGK-VEGF (red hatched) expression constructs were also analyzed for VEGF production. (B) Northern blot (top panel) and RT-PCR (bottom panel) analyses of VEGF transcripts in wild-type, c- $m y c^{+/-}$, and c-myc ${ }^{-/-}$ ES cells, and in c-myc $c^{-/-}$ES cells transduced with the PGK-Myc or PGK-VEGF vectors (c-myc $c^{-/-} / \mathrm{Myc}$ and c-myc $c^{-/-} /$VEGF). Northern blots were hybridized with murine VEGF and actin probes. RT-PCR analyses of VEGF, N-myc, and GAPDH were determined. (C) Defects in $V E G F$ expression are manifest in c- $m y c^{-/-}$embryos in vivo. In situ hybridization with a $V E G F$ antisense probe on wild-type and c- $m y c^{-1-}$ E8.5 embryo sections. Arrow indicates position of yolk sacs. Hybridization with the control sense VEGF probe failed to reveal signal (data not shown). (D) Myc activation is sufficient to induce VEGF expression. RT-PCR analyses of VEGF expression in primary MEFs and c-myc-null HO.15.19.3 Ratla fibroblasts engineered to express a conditionally inducible form of c-Myc, Myc-ER ${ }^{\mathrm{TM}}$, are shown. Cells were starved of serum overnight and then treated with 4-HT alone $(1 \mu \mathrm{M})$. RNA was isolated at the indicated intervals, and RT-PCR analyses of VEGF, ODC, and GAPDH expression were performed. (E) VEGF protein levels are induced by c-Myc in primary and immortal fibroblasts. (Top panels) Levels of VEGF protein were determined by immunoblot analyses from primary MEFs engineered to express Myc-ER ${ }^{\mathrm{TM}}$. Cells were treated with 4-HT for the indicated intervals, and VEGF protein levels were determined. $\beta$-Actin protein levels were determined as a loading control. (Bottom panels) VEGF protein levels were determined in wild-type (TGR1) and c- $\mathrm{myc}^{-/-}$(HO15.19.3) Ratla-derived fibroblasts, and in these cells engineered to overexpress c-Myc.

to the addition of 4-HT. Although Chx treatment alone induced significant levels of VEGF transcripts, these were not further elevated following activation of Myc$\mathrm{ER}^{\mathrm{TM}}$. In contrast, $\mathrm{ODC}$ was still induced by Myc-ER ${ }^{\mathrm{TM}}$ in the presence of Chx (Supplementary Fig. 4; see Supplementary Material at http://www.genesdev.org). Therefore, Myc appears to activate VEGF expression in an indirect fashion. In support of this idea, the mouse VEGF promoter/regulatory region, which contains one perfect CACGTG Myc-consensus-binding sequence (Blackwell et al. 1993), is not responsive to Myc in transient promoter-luciferase reporter assays (negative data not shown). Thus, although c-Myc is necessary for VEGF expression in ES cells and in vivo, and is sufficient to in- duce VEGF RNA, c-Myc appears to regulate $V E G F$ expression in an indirect fashion.

\section{VEGF rescues growth and differentiative defects of $c$-myc ${ }^{-/-}$progenitors}

The reduced VEGF levels expressed by c-myc $c^{-/-}$ES cells (Fig. 6A) suggested that their defects in EB formation could be caused by deficits in VEGF. Indeed, overexpression of VEGF in c- $\mathrm{myc}^{-/-}$ES cells partially rescued their ability to form EBs (Fig. 7A). Furthermore, as expected, $\mathrm{c}-\mathrm{myc}^{-/-}$ES cells engineered to reexpress c-Myc were comparable to wild-type ES cells in their ability to form EBs (Fig. 7A), proving that this defect is also intrinsic. 

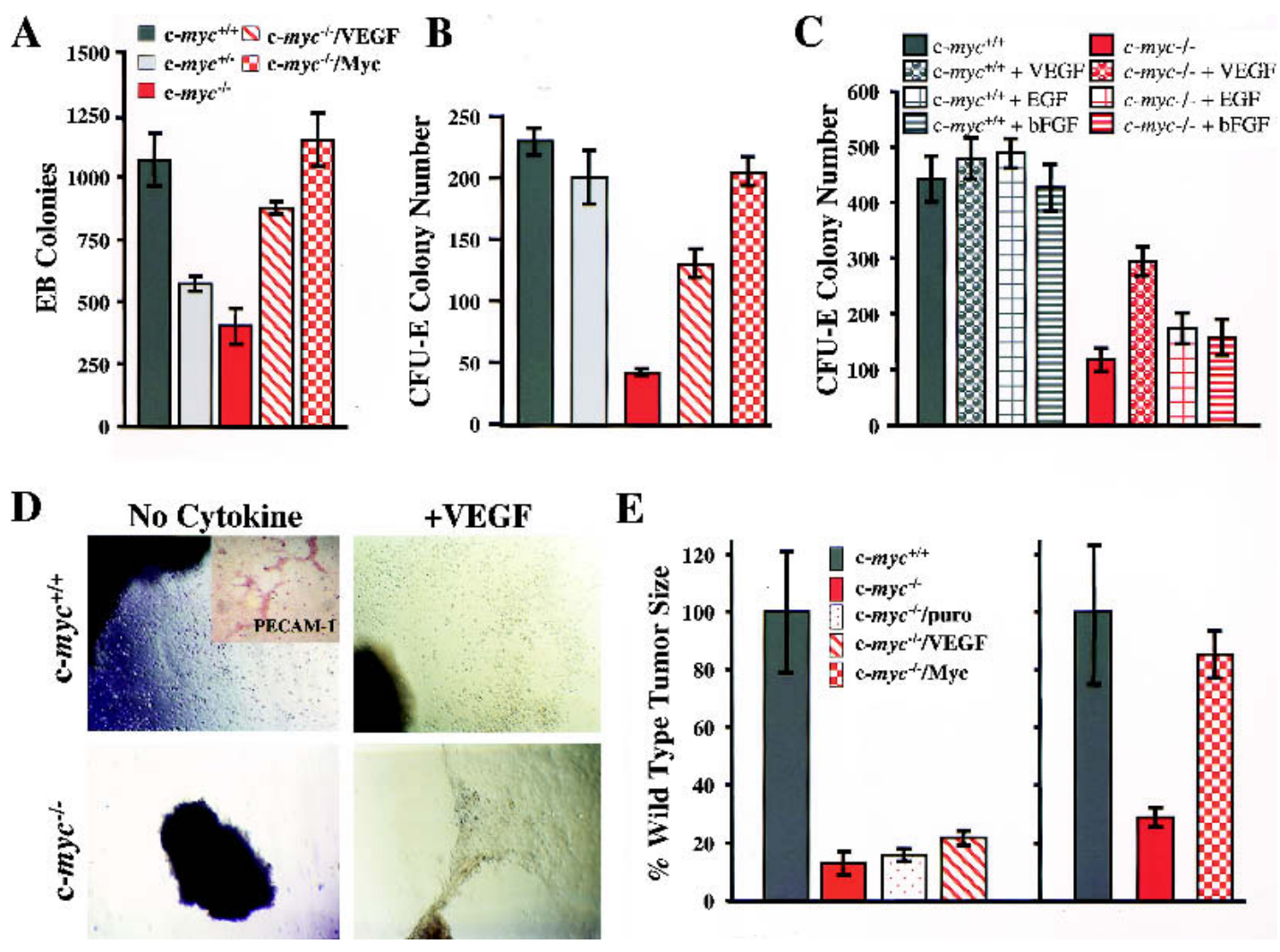

Figure 7. VEGF rescues growth but not tumorigenic defects of c-myc $c^{-/-}$progenitors. (A) VEGF expression or the restoration of Myc rescues primary differentiation of $\mathrm{c}-\mathrm{myc}^{-/-} \mathrm{ES}$ cells. The results shown are the mean of two experiments performed in quadruplicate. (B) VEGF expression or the restoration of c-Myc rescues secondary CFU-E colony formation of c-myc ${ }^{-/-}$EBs. The data shown are representative of three experiments performed in duplicate. The mean number of colonies $+/-$ the standard deviation is shown. $(C)$ The addition of exogenous VEGF, but not EGF or bFGF (all $10 \mathrm{ng} / \mathrm{mL}$ ), rescues CFU-E colony formation of c-myc ${ }^{-/-}$EBs. Day 7 EBs were harvested and then plated in methylcellulose with Epo $+/-$ the indicated cytokines. The data shown are representative of three experiments performed in duplicate. The mean number of colonies $+/-$ the standard deviation is shown. $(D)$ Yolk sac explant culture of E8.5 yolk sacs from wild-type (upper panels) or c-myc ${ }^{-/-}$(lower panels) embryos in serum-free medium (no cytokine) or in serum-free medium supplemented with $10 \mathrm{ng} / \mathrm{mL}$ VEGF (+VEGF). Photomicrographs were taken after $5 \mathrm{~d}$ of culture. (Inset at top left panel) Immunohistochemical staining of endothelial cells growing from these cultures with PECAM-1 antibody. $(E)$ c-Myc, but not VEGF, expression rescues defects in tumor growth inherent to c- $m y c^{-/-}$ES cells. The weight of tumors arising in Scid mice following injection of $2 \times 10^{6}$ of the indicated ES cells is shown (wild-type, dark gray; c- $m y c^{-/-}$, red; c- $m y c^{-/-} /$puro, red speckled; c-myc $c^{-/-} /$VEGF, red hatched; $\mathrm{c}-\mathrm{myc}^{-/-} / \mathrm{Myc}$, red checkerboard). The frequency of teratoma formation was as follows: $\mathrm{c}-\mathrm{myc}^{+/+}, 100 \%$; $\mathrm{c}-\mathrm{myc}^{-/-}, 50 \%$; c- $m y c^{-1-} / \mathrm{Myc}, 80 \%$; c- $m y c^{-/-} /$VEGF, $80 \%$.

The significant defects in CFU-E colony formation by $\mathrm{c}-\mathrm{myc}^{-/-}$-derived EBs and their modest defects in generating other hematopoietic colonies (Fig. 4C; Supplementary Fig. 2; see Supplementary Material at http://www. genesdev.org) could also be caused by deficits in VEGF expression. We therefore evaluated secondary colony formation in EBs derived from the c- $\mathrm{myc}^{-/-}$ES cells engineered to express VEGF or c-Myc. As expected, all defects inherent to c- $\mathrm{yyc}^{-/-} \mathrm{EBs}$ were rescued in $\mathrm{c}-\mathrm{myc}^{-/-}$ cells engineered to express c-Myc (Fig. 7B; Supplementary Fig. 2; see Supplementary Material at http://www. genesdev.org). In addition, partial rescue of these defects was also evident in c- $\mathrm{yyc}^{-/-}$ES cells engineered to overexpress VEGF (Fig. 7B).

The partial rescue of secondary colony formation in c- $m y c^{-/-}$ES cells by VEGF could simply reflect the ability of any growth factor to potentiate this response. We therefore treated wild-type and c- $m y c^{-/-}$EBs with VEGF, epidermal growth factor (EGF), or basic fibroblast growth factor (bFGF) and evaluated their effects on CFU-E formation. None of the cytokines affected CFU-E formation by wild-type EBs, and, as expected, VEGF addition partially rescued c- $\mathrm{myc}^{-/-}$-derived CFU-E formation. In contrast, the addition of EGF or bFGF did not significantly enhance CFU-E colony formation of EBs derived from c- $m y c^{-/-}$ES cells (Fig. 7C).

In vitro culture of isolated yolk sac explants gives rise to endothelial cells (Palis et al. 1995). We therefore assessed whether c-myc ${ }^{-/-}$yolk sac defects were also linked to VEGF. Sheets of endothelial-like cells grew from yolk sac explants from wild-type embryos, and their growth was not enhanced by the addition of VEGF (Fig. 7D). IHC analyses confirmed that these included endothelial cells that expressed PECAM-1 ${ }^{+}$ 
(Fig. 7D, inset). In contrast, yolk sac explants from c- $\mathrm{myc}^{-/-}$embryos failed to grow, yet their growth was fully restored by simply adding VEGF to the medium (Fig. 7D). Therefore, VEGF alone is sufficient to rescue the growth defects inherent to $\mathrm{c}-\mathrm{myc}^{-/-}$yolk sac endothelial cells.

The impaired tumorigenic potential of $\mathrm{c}-m y c^{-/-} \mathrm{ES}$ cells could be caused by intrinsic defects in c-Myc and/or VEGF expression. We therefore assessed the tumorigenic potential of $\mathrm{c}-\mathrm{myc}^{-/-}$ES cells engineered to express cMyc or VEGF. As expected, expression of c-Myc in $\mathrm{c}-\mathrm{myc}^{-/-}$ES cells fully restored their tumorigenic potential (Fig. 7E). In contrast, expression of VEGF in c-myc $c^{-/-}$ ES cells did not restore full tumor growth (Fig. 7E). Thus, although VEGF is sufficient to promote growth of $\mathrm{c}-\mathrm{myc}^{-/-}$yolk sac endothelial cells, simply providing VEGF does not rescue the impaired tumorigenic potential of $\mathrm{c}-\mathrm{myc}^{-/-} \mathrm{ES}$ cells. Thus, c-Myc must have other targets in addition to VEGF that contribute to tumorigenesis and the angiogenic switch.

$c-M y c$ is required for proper expression of the angiogenic network

The impaired tumorigenic potential of $\mathrm{c}-\mathrm{myc}^{-/-}$ES cells engineered to overexpress VEGF could be owing to defects in the expression of other angiogenic regulators. We therefore determined the levels of TSP-1, which inhibits angiogenesis, and of ANG-1 and ANG-2, which also regulate angiogenesis (Good et al. 1990; Hawighorst et al. 2002). Interestingly, RT-PCR analyses showed that TSP-1 levels were low in wild-type ES cells and in $\mathrm{c}-\mathrm{myc}^{-/-}$ES cells engineered to express c-Myc, but were markedly elevated in c- $\mathrm{myc}^{-/-}$ES cells and in these cells engineered to overexpress VEGF (Fig. 8A). Similarly, lev- els of $A N G-1$ were higher in c-myc ${ }^{-/-}$versus wild-type ES cells, whereas $A N G$-2 expression was compromised in c- $m y c^{-/-}$ES cells (Fig. 8A). To address whether c-Myc loss also affected the expression of these cytokines in vivo, we isolated RNA from dissected E9.5 yolk sacs derived from wild-type and $\mathrm{c}-\mathrm{myc}^{-/-}$embryos. Although RT-PCR analyses showed no significant differences in the levels of Tie2, there were again marked differences in the expression of $A N G-1, A N G-2, T S P-1$, and VEGF (Fig. $8 \mathrm{~B})$. In $\mathrm{c}-\mathrm{myc}^{-/-}$yolk sacs there were significant reductions in $A N G-2$ and $V E G F$, whereas the expression of ANG-1 and TSP-1 was highly elevated. Therefore, c-Myc is required for the proper expression of both positive and negative regulators of angiogenesis.

The binding of VEGF to its receptors induces a positive autoregulatory loop that up-regulates Flk-1 and Flt-1 expression (Shen et al. 1998). We therefore evaluated the expression of the VEGF receptors. Indeed, RT-PCR analyses showed that the expression of Flk-1 and Flt-1 were dramatically reduced in c- $\mathrm{myc}^{-/-}$ES cells (Fig. 8A) and yolk sacs (Fig. 8B). Therefore, loss of c-Myc also disables the expression of Flk-1 and Flt-1.

\section{Discussion}

The mechanisms by which c-Myc promotes cell growth, cell division, and transformation are not resolved. However, to induce proper cell growth and cell cycle traverse, c-Myc must coordinate many events. The data presented here suggest that c-Myc promotes cell growth and transformation by functioning as a master regulator of vital growth factors that are also required for development. Importantly, these findings explain why MYC activation is so pervasive in cancer: Myc functions are required to coordinate the expression of cytokines that or-
Figure 8. RT-PCR analyses of angiogenic and anti-angiogenic factors in $\mathrm{c}-\mathrm{myc}^{-1-} \mathrm{ES}$ cells and c-myc ${ }^{-/-}$yolk sacs. $(A$, left $)$ RTPCR analyses of TSP-1 expression in wildtype, c- $m y c^{-/-}$, and c- $m y c^{-/-}$ES cells transduced with the PGK-Myc or PGK-VEGF vectors $\left(\mathrm{c}-\mathrm{myc}^{-/-} / \mathrm{Myc}\right.$ and $\left.\mathrm{c}-\mathrm{myc}^{-/-}\right)$ VEGF). RNA was isolated from exponentially growing cells cultured in mLIF. $(A$, right) RT-PCR analyses of TSP-1, VEGF, ANG-1, ANG-2, Flk-1, Flt-1, and GAPDH expression in wild-type versus c-myc ${ }^{-/-}$ES cells. (B) RT-PCR analyses of ANG-1, ANG-2, Tie2, VEGF, TSP-1, Flk-1, Flt-1, and $G A P D H$ expression in E9.5 wild-type and $\mathrm{c}-\mathrm{myc}^{-/-}$yolk sacs.

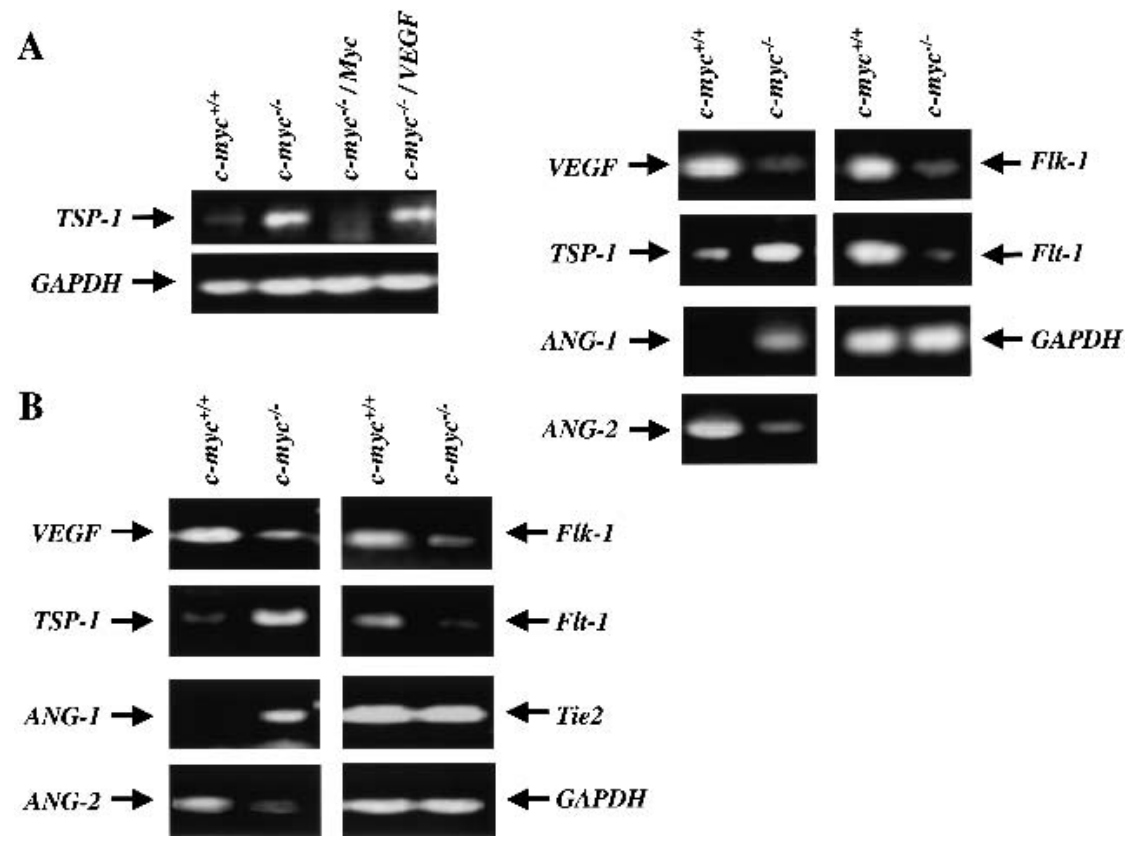


chestrate the angiogenic switch necessary for tumor progression.

\section{$c-M y c$ is required for vasculogenesis and primitive erythropoiesis}

Loss of VEGF or its receptors compromises vascular and hematopoietic development. Similarly, our rederivation of $\mathrm{c}-\mathrm{myc}^{+/-}$mice allowed us to establish that the lethality of c-Myc-deficient embryos is associated with profound defects in vasculogenesis, angiogenesis, and primitive erythropoiesis. Virtually all of the vasculature is missing in c-myc $\mathrm{c}^{-/-}$embryos, and this is associated with a drastic reduction in the numbers of PECAM- $1^{+}$endothelial cells. The failure of the vasculature in $\mathrm{c}-\mathrm{myc}^{-/-}$ embryos likely contributes to their lethality, and the resulting anemic state may also account for the developmental arrest of the pericardium and neural tube seen in

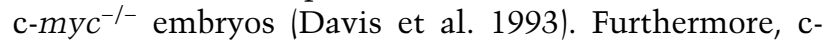
Myc loss should also compromise proper vascular contacts of the embryo with the placenta. At E7.5 c-myc is expressed in the ectoplacental cone, the allantois, and extraembryonic ectoderm (Downs et al. 1989), embryonic structures required for contact between the maternal and fetal blood systems. Notably, the failure to establish these connections appears responsible for embryonic lethality in several mouse knockouts (Ihle 2000). However, the defects in the vasculature within the $\mathrm{c}-\mathrm{myc}^{-/-}$embryo would be equally lethal.

c-Myc is highly expressed in PECAM- $1^{+}$endothelial cells of the yolk sac mesoderm, which harbors the hemangioblast progenitor that gives rise to the primitive vasculature and to primitive hematopoietic cells. The majority of the data support the concept that c-Myc function is required for the generation of the vascular system, and that defects in primitive erythropoiesis may be secondary to the collapse of the vasculature, as some primitive erythroblasts can be detected in c- $m y c^{-/-}$embryos. However, quantitative defects in hematopoietic colony formation are evident in $\mathrm{c}-\mathrm{myc}^{-/-} \mathrm{ES}$ cells, and these defects are more profound in $\mathrm{c}-\mathrm{myc}^{-/-}$yolk sacs. Thus, it appears that c-Myc loss also compromises, at least in a quantitative sense, the primitive hematopoietic stem cell.

In addition to their remarkable similarity to $F 1 k-1^{-/-}$ mice, other knockout mouse models also have striking parallels to c- $\mathrm{myc}^{-/-}$embryos. In particular, the site of c-Myc expression in yolk sac endothelial cells overlaps with that reported for the hypoxia regulators HIF- $1 \alpha$ and ARNT, and the phenotypes of HIF-1 $\alpha$ - and ARNT-deficient mice are strikingly similar to that of $\mathrm{c}-\mathrm{myc}^{-/-}$ mice, as all die around E10.5, with marked defects in vasculogenesis and primitive erythropoiesis (Kozak et al. 1997; Maltepe et al. 1997; Iyer et al. 1998; Ryan et al. 1998; Adelman et al. 1999). Possible connections between c-Myc and HIF-1 $\alpha /$ ARNT are compelling, as cMyc functions are required for teratoma development when their size approaches that which would induce hypoxia, and angiogenesis is impaired in the small tumors that can be generated from c-Myc- and HIF- $1 \alpha$-de- ficient ES cells (Fig. 5; Ryan et al. 1998). However, we have shown that VEGF expression is robustly induced by hypoxia in c-myc $c^{-/-}$ES cells (T.A. Baudino and J.L. Cleveland, unpubl.). Thus, c-Myc is not required for $V E G F$ induction during the hypoxia response. However, it remains possible that $\mathrm{HIF}-1 \alpha$ and ARNT regulate $V E G F$ in a distinct manner and/or that they function downstream of c-Myc. Regardless, both of these pathways are required for proper development of the vasculature.

\section{$c-M y c$ is essential for the angiogenic switch}

One important obstacle that likely must be bypassed during Myc-induced tumorigenesis is disabling apoptotic regulators, such as the ARF-Mdm2-p53 pathway (Zindy et al. 1998; Eischen et al. 1999). However, for continued growth and survival, a tumor must promote angiogenesis, and our studies and those of others directly link angiogenesis with c-Myc. With only one exception (Barr et al. 2000), studies have established that Myc activation is sufficient to trigger the expression of VEGF (Brandvold et al. 2000; Pelengaris et al. 1999, 2002; Okajima and Thorgeirsson 2000), whereas it suppresses the expression of the anti-angiogenic factor TSP-1 (Tikhonenko et al. 1996). Furthermore, continuous Myc activity is necessary to sustain VEGF expression and angiogenesis (Pelengaris et al. 1999, 2002). The results presented here expand the role of Myc, by establishing that c-Myc is essential for the angiogenic switch during tumor progression. This conclusion is supported by: (1) the impaired tumorigenic potential of c-myc $c^{-/-}$ES cells; (2) the failure of $\mathrm{c}-\mathrm{myc}^{-/-} \mathrm{ES}$ cells to sustain physiological levels of VEGF and to properly regulate other angiogenic factors; and $(3)$ the sparse vascularization of $\mathrm{c}-\mathrm{myc}^{-/-}$ES-cellderived tumors. Importantly, all of these defects are intrinsic to c-Myc loss. Thus, at least in ES-cell-derived tumors, c-Myc is the angiogenic switch, and this may be the case in other tumor types as well. If true, these findings explain why Myc overexpression is so common in cancer, as tumors expressing Myc would have a considerable proliferative and survival advantage. Furthermore, c-Myc's function as the angiogenic switch is also essential during development, as c- $m y c^{-/-}$embryos fail to form a vasculature, and to properly express angiogenic factors.

A principle established by these studies is that Myc is essential for the proper regulation of many components of the angiogenic network, including both positive (VEGF and ANG-2) and inhibitory (TSP-1) cytokines, as well as the VEGF receptors themselves. It remains to be established whether other cytokines that regulate angiogenesis are also regulated by c-Myc, and this seems likely given the strict Myc-dependency of angiogenesis.

A second principle supported by these findings is that coordinate regulation of the angiogenic network by Myc is required for tumor angiogenesis, whereas alterations in only a single cytokine may be relevant for cell proliferation. In particular, the addition of VEGF alone fully rescues the in vitro growth defects of $\mathrm{c}-\mathrm{myc}^{-/-}$yolk sac 
explants. This scenario contrasts to tumorigenesis, where VEGF overexpression alone fails to rescue defects of c- $\mathrm{myc}^{-/-}$ES cells in tumor development, and does not alter the defects in the expression of other angiogenic or anti-angiogenic cytokines in c- $\mathrm{myc}^{-/-}$ES cells. A similar scenario likely contributes to the profound defects in vasculogenesis during development in c- $\mathrm{myc}^{-/-} \mathrm{em}-$ bryos, as again there are profound alterations in the expression of both angiogenic and anti-angiogenic factors. Thus, providing or overexpressing a single angiogenic factor such as VEGF is unlikely to rescue defects of $\mathrm{c}-\mathrm{myc}^{-/-}$embryos in vivo, and this could only be achieved by proper restoration of Myc functions.

\section{$c-M y c$ is required for the coordinate expression of angiogenic regulators}

Numerous Myc target genes have been identified that perform various functions in metabolism, cell cycle traverse, cell growth, and apoptosis. However, only a handful of targets ascribed to Myc are direct (Oster et al. 2002), and the results presented here suggest a compelling alternative, whereby Myc induces a broad response by regulating the expression of cytokines that trigger pathways required for cell growth and division. However, these findings do not imply that Myc regulates the expression of all cytokines. Furthermore, the effects of c-Myc loss on VEGF signaling, at least in ES cells, are not absolute, as c- $\mathrm{myc}^{-/-}$ES cells still express low levels of $V E G F$. This could be owing to other regulators of VEGF expression (Flamme et al. 1997) or to N-Myc, which is also expressed in ES cells and during embryonic development (Downs et al. 1989), and is functionally redundant for c-Myc (Malynn et al. 2000). However, the levels of N-Myc expressed in ES cells fail to supplant c-Myc in supporting VEGF expression and are not sufficient to promote full tumor development. Thus, it appears that a specific threshold of Myc protein must be achieved to regulate the angiogenic network.

The precise mechanism by which c-Myc controls the expression of angiogenic factors is not resolved, yet $V E G F$ regulation appears to be indirect. Although the induction of VEGF RNA by c-Myc in fibroblasts is as robust as that of $O D C$, a direct Myc target, our analyses indicate that VEGF induction by Myc requires de novo protein biosynthesis (Supplementary Fig. 4; see Supplementary Material at http://www.genesdev.org) Furthermore, the VEGF promoter-regulatory region, which contains one perfect CACGTG Myc consensus element, is not responsive to c-Myc in transient transfection assays, and c-Myc does not occupy this E-box in chromatin immunoprecipitation assays of ES cells (data not shown). Indeed, at this juncture it is possible that c-Myc indirectly regulates $V E G F$ RNA levels by affecting the turnover of VEGF RNA. Regulation of VEGF RNA stability during hypoxia and in other scenarios is well documented (Stein et al. 1995; White et al. 1995), and Myc overexpression appears to regulate TSP-1 RNA levels by somehow altering its half-life (Tikhonenko et al. 1996).

\section{Myc functions in tumor progression}

The requirement for Myc for the proper expression of angiogenic factors has profound implications. Most importantly, it suggests a nonredundant role for Myc in regulating the expression of vital cytokines during gastrulation, vasculogenesis, angiogenesis, and during tumor progression. Nonetheless, c- $m y c^{-/-}$ES cells do grow, can undergo myeloid and erythroid differentiation in vitro, and can also form small tumors in vivo. Thus, the combined effects of c-Myc loss are not absolute, but are rather quantitative, as one might expect for reductions in essential cytokines. In turn, the failure to produce appropriate levels of cytokines should limit the net growth of a particular tissue. The recent analyses of the conditional c-myc knockout in mice support this scenario, in showing that c-Myc loss results in the reduction of cell numbers rather than changes in cell size (de Alboran et al. 2001; Trumpp et al. 2001), in contrast to the analyses of the Drosophila knockout of dmyc (Johnston et al. 1999|. Thus, Myc's requirement in regulating cell numbers may simply reflect its ability to regulate the expression of growth factors essential for proliferation. This concept is particularly compelling when one considers which cytokines c-Myc regulates. In particular, the alterations in the expression of angiogenic factors in $\mathrm{c}-\mathrm{myc}^{-/-}$embryos is associated with a compromised vasculature, which would impair the delivery of essential cytokines, nutrients, and oxygen required for the growth of other embryonic tissues.

Overall the analyses of this and other c-Myc knockout mice, and of c- $\mathrm{myc}^{-/-}$yolk sac progenitors, MEFs, and lymphoid cells, have shown that c-Myc is required for cell proliferation. The findings presented here and in transgenic systems indicate that c-Myc's effects on tumor growth and progression result at least in part from its ability to regulate the expression of cytokines. Moreover, because c-Myc functions are essential to coordinate the expression of angiogenic factors required for tumor progression, approaches that disrupt c-Myc function may prove effective in anti-angiogenic tumor therapy.

\section{Materials and methods}

Rederivation of $\mathrm{c}-\mathrm{myc}^{+/-}$mice

The AB2.1 cell line, and the derived c- $m y c^{+/-}$and $c-m y c^{-/-}$ES cells were cultured on a feeder layer of $\gamma$-irradiated embryonic fibroblast cells in standard ES cell medium supplemented with 1000 units of $\mathrm{mLIF} / \mathrm{mL}$ (Chemicon). Conditions for blastocyst injection were as described (Bradley 1987). The primers used for genotyping the mice, using a PCR-based assay, were the following: Myc1 primer, 5'-CGAGCGTCACTGATAGTAGGG-3'; Myc2 primer, 5'-GCGACCGCAACATAGGATGGA-3'; NeoMyc primer, 5'-CATCTTGTTCAATGGCCGATCC-3'.

\section{Immunofluorescence and immunohistochemical analyses}

E8.5 and E9.5 embryos were harvested from pregnant females following timed matings of c- $\mathrm{myc}^{+/-}$intercrosses, and fixed for $24 \mathrm{~h}$ in $10 \%$ buffered formalin (4\% formaldehyde). Embryos were genotyped by PCR as described above. For cryosections, 
embryos were transferred to a $25 \%$ sucrose solution for $24 \mathrm{~h}$ before preparation of $7-\mu \mathrm{m}$ sections. $\mathrm{H} \& \mathrm{E}$ staining was performed using standard techniques. Immunofluorescence was performed as follows: sections were refixed in $10 \%$ formalin at room temperature (RT) for $20 \mathrm{~min}$, washed once in PBS, and blocked for $1 \mathrm{~h}$ with $1 \%$ BSA in PBS. Phycoerythrin (PE)-conjugated antibodies to Ter119 or PECAM-1 (Pharmingen) were incubated at RT for $2 \mathrm{~h}$ and washed three times in PBS. Slides were counterstained with DAPI prior to being mounted under glass coverslips and analyzed by confocal microscopy. A rabbit polyclonal antibody (6A10) specific to mouse c-Myc was generously provided by Stephen Hann (Vanderbilt University) and was used at a dilution of 1:50. Alexa ${ }^{488}$-conjugated anti-rabbit antibody (Pharmingen) was used as a secondary antibody to detect c-Myc-expressing cells. The specificity of the antibody was shown by analyses of c- $\mathrm{myc}^{-/-}$embryos and ES cells (data not shown). Immunohistochemistry was performed as follows: 4- $\mu \mathrm{m}$ sections were prepared from E8.5 embryos or ES cell teratomas embedded in paraffin. Sections were deparaffinized and rehydrated according to standard protocols. After permeabilization in $10 \mathrm{mM}$ Tris- $\mathrm{HCl}$ at $\mathrm{pH} 7.6$, with $20 \mu \mathrm{g} / \mathrm{mL}$ proteinase $\mathrm{K}$ for $15 \mathrm{~min}$, the embryos were preblocked in $5 \%$ goat serum and $1 \%$ BSA in PBS at RT for $1 \mathrm{~h}$, then stained overnight at $4^{\circ} \mathrm{C}$ with a monoclonal antibody specific to PECAM-1 (1:200 dilution; PharMingen) or $\alpha$-SMA (1:200 dilution; NeoMarkers) in PBS containing $1 \%$ BSA. Following three washes in PBS, primary antibody binding was detected using the Santa Cruz ABC staining system. The slides were then counterstained, mounted under glass coverslips, and observed by light microscopy. Additionally, embryos were stained overnight at $4{ }^{\circ} \mathrm{C}$ with an antibody specific to phosphohistone H3 at Ser 10 (1:200 dilution; Upstate Biotechnology). After three washes in PBS, anti-phosphohistone $\mathrm{H} 3$ antibody binding was detected with Cy3-conjugated secondary antibody to rabbit IgG (1:200; Jackson Laboratories). Slides were washed three times in PBS prior to being mounted under glass coverslips and analyzed by confocal microscopy.

\section{RT-PCR analyses}

Total RNA was isolated from yolk sacs using the mRNA Capture Kit (Roche) according to the method recommended by the manufacturer or from ES cells or Ratla fibroblasts using TRI reagent (Molecular Research Center). The cDNA templates for PCR were synthesized by reverse transcriptase (Roche) according to the protocol recommended by the manufacturer. Standard PCR was performed with the Taq PCR core kit (QIAGEN) using primer sets for VEGF, ODC, N-myc, TSP-1, ANG-1, ANG2, Tie2, Flk-1, and Flt-1. RNA levels were standardized to $G A P D H$. PCR products were analyzed by standard agarose gel electrophoresis.

\section{Northern blot analysis}

Total RNA was isolated as described above. Then $20 \mu \mathrm{g}$ total RNA from each sample was separated by electrophoresis and transferred to a Protran membrane. Membranes were probed with the coding portion of VEGF [kindly provided by G. Breier (Max Planck Institute, Bad Nauheim, Germany)] or with the coding portion of $\beta$-actin to equalize loading of RNA.

\section{TUNEL assays}

Paraffin sections from E8.5 embryos were deparaffinized, rehydrated, and permeabilized as described above. Following permeabilization, sections were washed twice in PBS and tested for evidence of apoptosis by TUNEL (terminal deoxynucleotidyl-

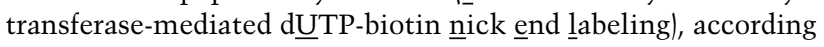
to the manufacturer's instructions (in situ cell death detection kit, fluorescein; Roche). At the end of the assay, slides were washed, covered, and examined by confocal microscopy.

\section{In vitro yolk sac explant culture}

E8.5 embryos and embryonic yolk sac tissue were harvested from pregnant c- $\mathrm{myc}^{+/-}$females. Embryonic yolk sac tissue was dissected away from the embryo proper and cultured in Excell 600 media (JRH Biosciences), in the presence or absence of 10 $\mathrm{ng} / \mathrm{mL}$ VEGF (R\&D Systems). After culturing at $37^{\circ} \mathrm{C}$ in $5 \%$ $\mathrm{CO}_{2}$ for $5 \mathrm{~d}$, yolk sac cultures were photographed. Cells were allowed to grow onto glass coverslips, and PECAM-1 staining of cells was performed as described above.

\section{Embryonic stem cell differentiation}

Wild-type, c- $m y c^{+/-}$, and c- $m y c^{-/-}$AB2.1 ES cells [Davis et al. 1993, kindly provided by Allan Bradley (The Wellcome Trust Sanger Institute, Cambridge, U.K.)] were maintained in culture in the presence of 1000 units of mLIF. To initiate primary differentiation, ES cells were harvested and plated in predifferentiation cultures in the presence of mLIF, at a density of $1 \times 10^{5} \mathrm{cells} / 25-\mathrm{cm}^{2}$ flask, for $3 \mathrm{~d}$. Cells were harvested at $40 \%-$ $50 \%$ confluency and plated in primary differentiation cultures as follows: $0.9 \%$ basic methylcellulose (Stem Cell Technologies), 15\% differentiation FBS (Stem Cell Technologies), $2 \mathrm{mM}$ L-glutamine, $150 \mathrm{mM}$ monothiolglycerol, and $40 \mathrm{ng} / \mathrm{mL} \mathrm{mSCF}$ (R\&D Systems) in IMDM, at a density of $5 \times 10^{3}$ cells/plate. Cultures were assessed after culturing at $37^{\circ} \mathrm{C}$ and $5 \% \mathrm{CO}_{2}$ for $5 \mathrm{~d}$ or $7 \mathrm{~d}$ for EB formations. Secondary hematopoietic colony assays were performed by disrupting either day 5 or day $7 \mathrm{EBs}$ and then plating cells and recombinant cytokines specific for each of the assays (see below) with MethoCult M3230 (Stem Cell Technologies). Assays were plated in $35-\mathrm{mm}$ dishes in duplicate and cultured at $37^{\circ} \mathrm{C}$ and $5 \% \mathrm{CO}_{2}$. For the CFU-E assay, $5 \times 10^{4}$ cells/dish were cultured in $1 \mathrm{U} / \mathrm{mL}$ Epo, and benzidinepositive CFU-E colonies were scored at day 4 . For the BFU-E assay, $1 \times 10^{5}$ cells/dish were cultured in $3 \mathrm{U} / \mathrm{mL}$ Epo and 30 $\mathrm{U} / \mathrm{mL}$ IL-3, and benzidine-positive BFU-E colonies were scored at day 8. In addition, ES cells were transduced with a PGK-Puro, PGK-Myc-Puro, or PGK-VEGF-Puro vector [the PGK-Puro vector was kindly provided by James Downing (St. Jude Children's Research Hospital, Memphis, TN)]. ES cells were transduced, and colonies were selected as described (Lexicon Genetics). Transfectants were selected using $5 \mu \mathrm{g} / \mathrm{mL}$ puromycin. The resulting transfectants were also used in the differentiation and tumorigenic assays described above. To evaluate effects of VEGF, bFGF, or EGF on secondary CFU-E colony formation by $\mathrm{c}-\mathrm{myc}^{-/-}$-derived EBs, wild-type and $\mathrm{c}-\mathrm{myc}^{-/-}$day $7 \mathrm{EBs}$ were dispersed into single-cell suspensions and replated in methylcellulose plus Epo as described above.

\section{In situ hybridization}

E8.5 wild-type and c-myc ${ }^{-/-}$embryos were embedded in paraffin and sectioned $(6 \mu \mathrm{m})$. After deparaffinization and rehydration, slides were hybridized to a 981-bp VEGF antisense riboprobe (Breier et al. 1992) or to the corresponding VEGF sense riboprobe (kindly provided by G. Breier). cRNA riboprobes were transcribed from $\mathrm{T} 3$ and $\mathrm{T} 7$ RNA polymerase promoters and were labeled with $\left({ }^{33} \mathrm{P}\right) \mathrm{UTP}$ according to the manufacturer's instructions (Promega). In situ hybridization was performed using conventional methods. 


\section{Scid mouse tumor assays}

For injection of Scid mice, ES cells that had been cultured in mLIF were dissociated in $125 \mathrm{mM} \mathrm{NaCl}, 5 \mathrm{mM} \mathrm{KCl}, 50 \mathrm{mM}$ HEPES, $5 \mathrm{mM}$ glucose, $1 \mathrm{mM}$ EDTA (pH 7.4), washed once in the same buffer, and then resuspended in PBS. Then $2 \times 10^{6}$ cells were injected subcutaneously into each flank of 4-8-wk old Scid mice in a volume of $0.1 \mathrm{ml}$. Tumor weight in individual mice was determined $2-5$ wk following injection.

\section{ELISA measurement of VEGF}

Wild-type, c- $m y c^{+/-}, \mathrm{c}-\mathrm{myc}^{-/-}, \mathrm{c}-\mathrm{myc}^{-/-} / \mathrm{Myc}$, and c- $m y c^{-/-}$ VEGF AB2.1 ES cells were split into 6 well plates, and conditioned media was harvested from cultures $2 \mathrm{~d}$ after passage. Media harvested after passage of the ES cells was assayed for VEGF protein levels using a specific ELISA assay (R\&D Systems).

\section{Vascular analysis of teratomas}

Tumor-bearing animals were anesthetized, then immediately infused with $5.0 \mathrm{~mL}$ of a curable orange latex injection compound, Microfil MV-122 (Microfil). The compound was allowed to cure at $4^{\circ} \mathrm{C}$ overnight before harvesting the tumors. The tissue was cleared in increasing concentrations of glycerol, according to the manufacturer's protocol. The vascular architecture was visualized with a color digital camera (Nikon Coolpix 990).

\section{Acknowledgments}

The authors are grateful for the outstanding technical assistance of Chunying Yang, Linda Snyder, and Kristen Rothammer. We also thank the staff of our Animal Resources Center. We thank Gregor Breier for providing the VEGF riboprobe constructs, Randall Johnson for advice with latex injections of tumors, Stephen Hann for c-Myc antibody, John Sedivy for the c-mycnull Ratla fibroblasts, and Gerard Zambetti and members of our laboratories for their suggestions. We especially thank Allan Bradley for providing wild-type, c- $m \mathrm{yc}^{+/-}$, and c- $m y c^{-/-} \mathrm{AB} 2.1$ ES cells. This work was supported in part by grants DK44158 and CA76379 (J.L.C), DK42932 (J.N.I), Cancer Center CORE Grant CA21765, and by the American Lebanese Syrian Associated Charities (ALSAC). T.A.B. was supported by NRSA grant 1F32 DK10154-01.

The publication costs of this article were defrayed in part by payment of page charges. This article must therefore be hereby marked "advertisement" in accordance with 18 USC section 1734 solely to indicate this fact.

\section{References}

Adelman, D.M., Maltepe, E., and Simon, M.C. 1999. Multilineage embryonic hematopoiesis requires hypoxic ARNT activity. Genes \& Dev. 13: 2478-2483.

Askew, D.S., Ashmun, R.A., Simmons, B.C., and Cleveland, J.L. 1991. Constitutive c-myc expression in an IL-3-dependent myeloid cell line suppresses cell cycle arrest and accelerates apoptosis. Oncogene 6: 1915-1922.

Barr, L.F., Campbell, S.E., Diette, G.B., Gabrielson, E.W., Kim, S., Shim, and H., Dang, C.V. 2000. c-Myc suppresses the tumorigenicity of lung cancer cells and down-regulates vascular endothelial growth factor expression. Cancer Res. 60: $143-149$.

Bello-Fernandez, C., Packham, G., and Cleveland, J.L. 1993. Or- nithine decarboxylase is a transcriptional target of c-myc. Proc. Natl. Acad. Sci. 90: 7804-7808.

Blackwell, T.K., Huang, J., Ma, A., Kretzner, L., Alt, F.W., Eisenman, R.N., and Weintraub, H. 1993. Binding of myc proteins to canonical and noncanonical DNA sequences. Mol. Cell. Biol. 13: 5216-5224.

Bradley, A. 1987. Teratocarcinomas and embryonic stem cells. In Teratocarcinomas in embryonic stem cells: A practical approach (E.J. Robertson, ed.), pp. 113-157. IRL, Oxford.

Brandvold, K.A., Neiman, P., and Ruddell, A. 2000. Angiogenesis is an early event in the generation of myc-induced lymphomas. Oncogene 19: 2780-2785.

Breier, G., Albrecht, U., Sterrer, S., and Risau, W. 1992. Expression of vascular endothelial growth factor during angiogenesis and endothelial cell differentiation. Development 114: $521-532$.

Carmeliet, P. and Collen, D. 1999. Role of vascular endothelial growth factor and vascular endothelial growth factor receptors in vascular development. Curr. Top. Microbiol. Immunol. 237: 133-158.

Carmeliet, P., Ferreira, V., Breier, G., Pollefeyt, S., Kieckens, L., Gertsenstein, M., Fahrig, M., Vandenhoeck, A., Harpal, K., Eberhardt, C., et al. 1996. Abnormal blood vessel development and lethality in embryos lacking a single VEGF allele. Nature 380: 435-439.

Carmeliet, P., Dor, Y., Herbert, J.-M., Fukumura, D., Brusselmans, K., Dewerchin, M., Neeman, M., Bono, F., Abramovitch, R., Maxwell, P., et al. 1998. Role of HIF-1 $\alpha$ in hypoxiamediated apoptosis, cell proliferation and tumour angiogenesis. Nature 394: 485-490.

Choi, K., Kennedy, M., Kazarov, A., Papadimitriou, J.C., and Keller, G. 1998. A common precursor for hematopoietic and endothelial cells. Development 125: 725-732.

Davis, A.C., Wims, M., Spotts, G.D., Hann, S.R., and Bradley, A. 1993. A null $c$-myc mutation causes lethality before 10.5 days of gestation in homozygotes and reduced fertility in heterozygous female mice. Genes \& Dev. 7: 671-682.

de Alboran, I.M., O'Hagan, R.C., Gartner, F., Malynn, B., Davidson, L., Rickert, R., Rajewsky, K., DePinho, R.A., and Alt, F.W. 2001. Analysis of C-MYC function in normal cells via conditional gene-targeted mutation. Immunity 14: 45-55.

Downs, K.M., Martin, G.R., and Bishop, J.M. 1989. Contrasting patterns of myc and $\mathrm{N}$-myc expression during gastrulation of the mouse embryo. Genes \& Dev. 3: 860-869.

Eilers, M., Schirm, S., and Bishop, J.M. 1991. The MYC protein activates transcription of the $\alpha$-prothymosin gene. EMBO $J$. 10: $133-141$

Eischen, C.M., Weber, J.D., Roussel, M.F., Sherr, C.J., and Cleveland, J.L. 1999. Disruption of the ARF-Mdm2-p53 tumor suppressor pathway in Myc-induced lymphomagenesis. Genes \& Dev. 13: 2658-2669.

Evan, G.I., Wyllie, A.H., Gilbert, C.S., Littlewood, T.D., Land, H., Brooks, M., Waters, C.M., Penn, L.Z., and Hancock, D.C. 1992. Induction of apoptosis in fibroblasts by c-myc protein. Cell 69: 119-128.

Felsher, D.W. and Bishop, J.M. 1999. Reversible tumorigenesis by MYC in hematopoietic lineages. Mol. Cell 4: 199-207.

Ferrara, N., Carver-Moore, K., Chen, H., Dowd, M., Lu, L., O'Shea, K.S., Powell-Braxton, L., Hillan, K.J., and Moore, M.W. 1996. Heterozygous embryonic lethality induced by targeted inactivation of the VEGF gene. Nature 380: 439442.

Flamme, I., Frolich, T., and Risau, W. 1997. Molecular mechanisms of vasculogenesis and embryonic angiogenesis. J. Cell Physiol. 173: 206-210.

Fong, G.-H., Rossant, J., Gertsenstein, M., and Breitman, M.L. 
1995. Role of the Flt-1 receptor tyrosine kinase in regulating the assembly of vascular endothelium. Nature 376: 66-70.

Good, D.J., Polverini, P.J., Rastinejad, F., Le, B.M., Lemons, R.A., Frazier, W.A., and Bouck, N.P. 1990. A tumor suppressor-dependent inhibitor of angiogenesis is immunologically and functionally indistinguishable from a fragment of thrombospondin. Proc. Nat1. Acad. Sci. 89: 6624-6628.

Hanahan, D. 1997. Signaling vascular morphogenesis and maintenance. Science 277: 48-50.

Hanahan, D. and Folkman, J. 1996. Patterns and emerging mechanisms of the angiogenic switch during tumorigenesis. Cell 86: 353-364.

Hawighorst, T., Skobe, M., Striet, M., Hong, Y.K., Velasco, P., Brown, L.F., Riccardi, L., Lange-Asschenfeldt, B., and Detmar, M. 2002. Activation of the tie2 receptor by angiopoietin-1 enhances tumor vessel maturation and impairs squamous cell carcinoma growth. Am. J. Pathol. 160: 13811392.

Ihle, J.N. 2000. The challenges of translating knockout phenotypes into gene function. Cell 102: 131-134.

Ilkuta, K., Kina, T., MacNeil, I., Uchida, N., Peailt, B., Chien, Y., and Weissman, I.L. 1990. A developmental switch in thymic lymphocyte maturation potential occurs at the level of hematopoietic stem cells. Cell 62: 863-874.

Iyer, N.V., Kotch, L.E., Agani, F., Leung, S.W., Laughner, E., Wenger, R.H., Gassmann, M., Gearhart, J.D., Lawler, A.M., $\mathrm{Yu}, \mathrm{A} . Y$. , et al. 1998. Cellular and developmental control of $\mathrm{O}_{2}$ homeostasis by hypoxia-inducible factor $1 \alpha$. Genes \& Dev. 12: 149-162.

Jain, M., Arvanitis, C., Chu, K., Dewey, W., Leonhardt, E., Trinh, M., Sundberg, C.D., Bishop, J.M., and Felsher, D.W. 2002. Sustained loss of a neoplastic phenotype by brief inactivation of MYC. Science 297: 102-104.

Johnston, L.A., Prober, D.A., Edgar, B.A., Eisenman, R.N., and Gallant, P. 1999. Drosophila myc regulates cellular growth during development. Cell 98: 779-790.

Kennedy, M., Firpo, M., Choi, K., Wall, C., Robertson, S., Kabrun, N., and Keller, G. 1997. A common precursor for primitive erythropoiesis and definitive haematopoiesis. $\mathrm{Na}$ ture 386: 488-493.

Kerbel, R.S., Viloria-Petit, A., Okada, F., and Rak, J. 1998. Establishing a link between oncogenes and tumor angiogenesis. Mol. Med. 4: 286-295.

Kozak, K.R., Abbott, B., and Hankinson, O. 1997. ARNT-deficient mice and placental differentiation. Dev. Biol. 191: 297305.

Maltepe, E., Schmidt, J.V., Baunoch, D., Bradfield, C.A., and Simon, M.C. 1997. Abnormal angiogenesis and responses to glucose and oxygen deprivation in mice lacking the protein ARNT. Nature 386: 403-407.

Malynn, B.A., Moreno de Alboran, I., O'Hagan, R.C., Bronson, R., Davidson, L., DePinho, R.A., and Alt, F.W. 2000. N-myc can functionally replace c-myc in murine development, cellular growth, and differentiation. Genes \& Dev. 14: 13901399.

Mateyak, M.K., Obaya, A.J., Adachi, S., and Sedivy, J.M. 1997. Phenotypes of c-Myc-deficient rat fibroblasts isolated by targeted homologous recombination. Cell Growth Differ. 8: 1039-1048.

Mettouchi, A., Cabon, F., Montreau, N., Vernier, P., Mercier, G., Blangy, D., Tricoire, H., Vigier, P., and Binetruy, B. 1994. SPARC and thrombospondin genes are repressed by the c-jun oncogene in rat embryo fibroblasts. EMBO J. 13: 5668-5678.

Okajima, E. and Thorgeirsson, U.P. 2000. Different regulation of vascular endothelial cell growth factor expression by the ERK and p38 kinase pathways in v-ras, v-raf, and v-myc transformed cells. Biochem. Biophys. Res. Commun. 270: $108-111$.

Oster, S.K., Ho, C.S., Soucie, E.L., and Penn, L.Z. 2002. The myc oncogene: MarvelouslY Complex. Adv. Cancer Res. 84: 81154.

Palis, J., McGrath, K.E., and Kingsley, P.D. 1995. Initiation of hematopoiesis and vasculogenesis in murine yolk sac explants. Blood 86: 156-163.

Pelengaris, S., Littlewood, T.D., Khan, M., Elia, G., and Evan, G. 1999. Reversible activation of c-Myc in skin: Induction of a complex neoplastic phenotype by a single oncogenic lesion. Mol. Cell 3: 565-577.

Pelengaris, S., Khan, M., and Evan, G.I. 2002. Suppression of Myc-induced apoptosis in beta cells exposes multiple oncogenic properties of Myc and triggers carcinogenic progression. Cell 109: 321-334.

Risau, W. 1997. Mechanisms of angiogenesis. Nature 386: 671674.

Ryan, H.E., Lo, J., and Johnson, R.S. 1998. HIF-1 $\alpha$ is required for solid tumor formation and embryonic vascularization. EMBO J. 17: 3005-3015.

Shalaby, F., Rossant, J., Yamaguchi, T.P., Gertsenstein, M., Wu, X.-F., Breitman, M.L., and Schuh, A.C. 1995. Failure of blood island formation and vasculogenesis in Flk-1-deficient mice. Nature 376: 62-66.

Shen, B.Q., Lee, D.Y., Gerber, H.P., Keyt, B.A., Ferrara, N., and Zioncheck, T.F. 1998. Homologous up-regulation of KDR/ Flk-1 receptor expression by vascular endothelial growth factor in vitro. J. Biol. Chem. 273: 29979-29985.

Slack, J.L. and Bornstein, P. 1994. Transformation by v-src causes a transient induction followed by repression of mouse thrombospondin-1. Cell Growth Differ. 5: 1373-1380.

Stein, I., Neeman, M., Shweiki, D., Itin, A., and Keshet, E. 1995. Stabilization of vascular endothelial growth factor mRNA by hypoxia and hypoglycemia and coregulation with other ischemia-induced genes. Mol. Cell. Biol. 15: 5363-5368.

Tikhonenko, A.T., Black, D.J., and Linial, M.L. 1996. Viral Myc oncoproteins in infected fibroblasts down-modulate thrombospondin-1, a possible tumor suppressor gene. J. Biol. Chem. 271: 30741-30747.

Trumpp, A., Refaeli, Y., Oskarsson, T., Gasser, S., Murphy, M., Martine, G.R., and Bishop, G.M. 2001. c-Myc regulates mammalian body size by controlling cell number but not cell size. Nature 414: 768-773.

Volpert, O.V., Dameron, K.M., and Bouck, N. 1997. Sequential development of an angiogenic phenotype by human fibroblasts progressing to tumorigenicity. Oncogene 14: 14951502.

Wagner, R.C. 1980. Endothelial cell embryology and growth. Adv. Microcirc. 9: 45-75.

White, F.C., Carroll, S.M., and Kamps, M.P. 1995. VEGF mRNA is reversibly stabilized by hypoxia and persistently stabilized in VEGF-overexpressing human tumor cell lines. Growth Factors 12: 289-301.

Zindy, F., Eischen, C.M., Randle, D.H., Kamijo, T., Cleveland, J.L., Sherr, C.J., and Roussel, M.F. 1998. Myc signaling via the ARF tumor suppressor regulates p53-dependent apoptosis and immortalization. Genes \& Dev. 12: 2424-2433. 


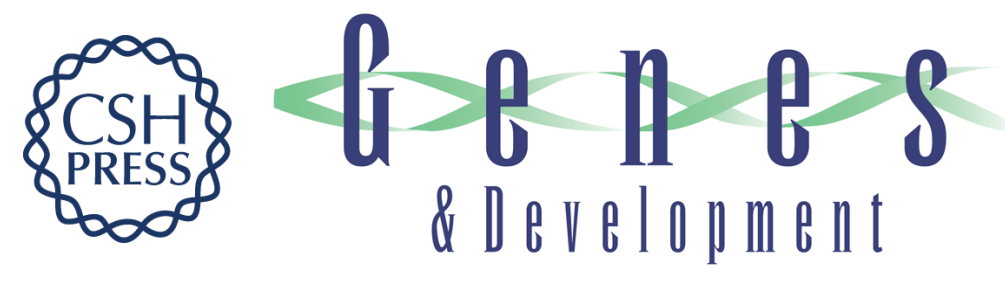

\section{c-Myc is essential for vasculogenesis and angiogenesis during development and tumor progression}

Troy A. Baudino, Catriona McKay, Helene Pendeville-Samain, et al.

Genes Dev. 2002, 16:

Access the most recent version at doi:10.1101/gad.1024602

Supplemental
Material http://genesdev.cshlp.org/content/suppl/2002/10/29/16.19.2530.DC1

References This article cites 53 articles, 22 of which can be accessed free at:

http://genesdev.cshlp.org/content/16/19/2530.full.html\#ref-list-1

License

Email Alerting

Receive free email alerts when new articles cite this article - sign up in the box at the top

Service

right corner of the article or click here.

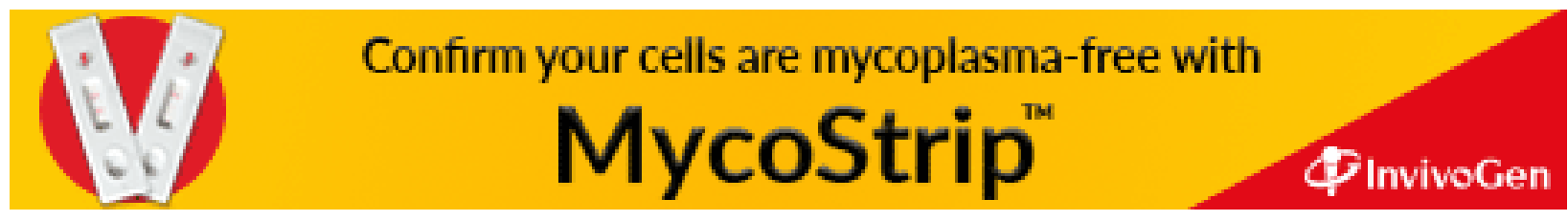

